\title{
Rural-Spatial Restructuring Promoted by Land-Use Transitions: A Case Study of Zhulin Town in Central China
}

\author{
Dong Han ${ }^{1,2}$, Jiajun Qiao ${ }^{1,2, *}$ and Qiankun Zhu ${ }^{2}$ \\ 1 Key Laboratory of Geospatial Technology for the Middle and Lower Yellow River \\ Regions (Henan University), Ministry of Education, Kaifeng 475004, China; dhan89@henu.edu.cn \\ 2 College of Environment and Planning, Henan University, Kaifeng 475004, China; Zhuqk@henu.edu.cn \\ * Correspondence: jjqiao@henu.edu.cn
}

check for updates

Citation: Han, D.; Qiao, J.; Zhu, Q. Rural-Spatial Restructuring Promoted by Land-Use Transitions: A Case Study of Zhulin Town in Central China. Land 2021, 10, 234. https:// doi.org/10.3390/land10030234

Academic Editor: Hualou Long

Received: 3 February 2021

Accepted: 22 February 2021

Published: 25 February 2021

Publisher's Note: MDPI stays neutral with regard to jurisdictional claims in published maps and institutional affiliations.

Copyright: (c) 2021 by the authors. Licensee MDPI, Basel, Switzerland. This article is an open access article distributed under the terms and conditions of the Creative Commons Attribution (CC BY) license (https:// creativecommons.org/licenses/by/ $4.0 /)$.

\begin{abstract}
Rural-spatial restructuring involves the spatial mapping of the current rural development process. The transformation of land-use morphologies, directly or indirectly, affects the practice of rural restructuring. Analyzing this process in terms of the dominant morphology and recessive morphology is helpful for better grasping the overall picture of rural-spatial restructuring. Accordingly, this paper took Zhulin Town in Central China as a case study area. We propose a method for studying rural-spatial restructuring based on changes in the dominant and recessive morphologies of land use. This process was realized by analyzing the distribution and functional suitability of ecologicalproduction-living (EPL) spaces based on land-use types, data on land-use changes obtained over a 30-year observation period, and in-depth research. We found that examining rural-spatial restructuring by matching the distribution of EPL spaces with their functional suitability can help to avoid the misjudgment of the restructuring mode caused by the consideration of the distribution and structural changes in quantity, facilitating greater understanding of the process of rural-spatial restructuring. Although the distribution and quantitative structure of Zhulin's EPL spaces have changed to differing degrees, ecological- and agricultural-production spaces still predominate, and their functional suitability has gradually increased. The spatial distribution and functional suitability of Zhulin are generally well matched, with $62.5 \%$ of the matched types being high-quality growth, and the positive effect of Zhulin's spatial restructuring over the past 30 years has been significant. We found that combining changes in EPL spatial area and quantity as well as changes in functional suitability is helpful in better understanding the impact of the national macro-policy shift regarding rural development. Sustaining the positive spatial restructuring of rural space requires the timely adjustment of local actors in accordance with the needs of macroeconomic and social development, and a good rural-governance model is essential.
\end{abstract}

Keywords: ecological-production-living spaces; spatial distribution; functional suitability evaluation; land-use transition; rural-spatial restructuring

\section{Introduction}

Over the past several decades, under the influence of urbanization, industrialization, informatization and globalization, the social, economic and spatial structures of rural areas have undergone significant changes [1,2]. Space is a carrier of various elements of the rural territorial system, and the reshaping of the socioeconomic structure of rural areas will inevitably lead to changes in this carrier, which in turn will lead to the restructuring of rural space [3-5]. Global industrialization and urbanization have triggered and will continue to trigger dramatic changes in rural space. In the Western world, the transition from a preindustrial economy to a knowledge-based economy took centuries [6-10], while in newly industrialized countries such as China, this is a more compressed process [11-14]. China's rural villages have undergone a transformational rural development process in just a few decades. Rapid urbanization and industrialization have led to significant changes 
in the industrial, employment and social structures of rural territories $[15,16]$. While contributing to urban and rural economic development, this has resulted in the conversion of large amounts of arable land into urban built-up land, leading to a drastic reduction in rural land and a shift in land use and ownership. The disorderly expansion of urban and rural built-up land has caused environmental pollution, ecological damage, and inefficient land use [17]. At the same time, unevenness in urban-rural development has led to serious rural population loss, rural aging, rural poverty and village depopulation [18]. The continued opening of the political, economic and cultural spheres to the outside world has allowed China to enjoy the dividends brought by globalization [19], while at the same time exacerbating the complexity of problems related to geographic change in rural China.

Theoretical research on rural-spatial restructuring is the foundation for solving rural problems. Moreover, the optimal reorganization of rural space is an important means for implementing a strategy for promoting rural revitalization and realizing the integrated development of both urban and rural areas. In this process, land-use transitions play an important role in promoting rural-spatial restructuring [17].

Due to the problems and challenges of China's urban and rural development process, in 2012, China began to implement the strategy of ecological civilization construction. As a result, China proposed changing rural-spatial development from a production-space-led model to an ecological-production-living (EPL) space model. The EPL space model is more comprehensive than the previous model and is an effective means for optimizing the spatial development pattern of China [20]. Promoting rural-spatial restructuring to optimize land use in this way will transform traditional rural areas through land concentration and large-scale operation, as well as optimizing village and industrial layouts. This will promote industrialization and the modernization of agriculture, optimize urban-ruralspatial patterns, build new urban-rural relationships and achieve integrated urban-rural development [21], thus alleviating urban-rural development conflicts [22]. Therefore, a profound analysis of the process of rural-spatial restructuring represented by the changes in EPL space morphologies, and the mechanism behind them, could enable correct human interventions to guide positive rural development. The restructuring of rural space is closely related to three important rural issues in China. Rural space provides a resource base and physical space for rural development. The optimization and reorganization of rural space is an important means for implementing a strategy of rural revitalization and realizing the integrated development of urban and rural areas.

Land-use morphology includes the dominant morphology and recessive morphology [17]. The dominant morphology refers to the structure of land use in a particular area over a fixed period, including characteristics such as the number (area and proportion) and spatial patterns of land-use types. The recessive morphology refers to a special form based on the explicit form and can be observed only by means of analysis, testing, monitoring and investigation, including the quality and function of land use [23]. Current research on rural-spatial restructuring is based mainly on the area, structure, distribution and other dominant morphological characteristics of regional land-use types [24], but not enough research focuses on quality, function, management methods and other recessive morphologies [17]. Many scholars focus on case studies, with an emphasis on the spatial needs of rural populations and socioeconomic development, as well as concentrating on the optimization and reorganization of rural space. For example, many researchers identify the time points when changes in the spatial morphology of farmland occur to analyze the transformation and restructuring process for agricultural-production space [25-27]. In terms of spatial patterns, agricultural land tends to be scattered and at a lower level of socioeconomic development. Socioeconomic development concentrates this phenomenon; thus, business patterns and landscape patterns are two main indicators for studying the spatial transformation and restructuring of agriculture [28]. The change in rural housing area per capita is a direct way to reflect the restructuring of rural life, which is influenced by both changes in total residential area and population migration [29]. There is substantial empirical evidence for the spatial distribution of rural living space in China, involving 
multiple scales and national/regional, municipal, county and village levels [30,31]. Spatial restructuring strategies for different types of village have been proposed to promote different models of rural-spatial restructuring [32,33], and empirical studies on the spatial restructuring of rural settlements in different regions have been conducted [34-36]. Long proposed that rural restructuring should be considered an integrated approach to optimizing urban-rural-spatial organization and promoting coordinated urban-rural development, recommending a land remediation approach to realizing rural-spatial restructuring [3]. It is thought that this will help to solve the problem of hollowed-out villages [37] and provide a comprehensive platform for rural revitalization [38]. These research results propose differing models of rural-spatial restructuring, specify future research ideas for rural-spatial restructuring, enrich the literature on rural-spatial restructuring, provide technical support and methodological guidance for different types of rural development planning, and have a beneficial impact on the practice of rural development in China.

However, limiting rural-spatial restructuring to the perspective of change in the explicit morphological characteristics of EPL spaces will lead to a deviation in our understanding of the patterns of rural-spatial restructuring, which will then lead to deviations in policy formulation and implementation. Undeniably, changes in quantity are an important characteristic of change in EPL spaces, and the disorder of the quantity structure of EPL spaces often leads to unsustainable spatial development and conflicting landscape functions [39]. For example, Yang et al. [22] analyzed the impact of change in the quantity structure of EPL spaces on the quality of the ecological environment, concluding that the transformation of agricultural-production land to urban and rural living land is the main factor behind the deterioration of regional ecological environmental quality. These authors propose that ecological space be further expanded through land reclamation and greening to provide a solid ecological barrier for urban development. From a macro-policy perspective, the results of that study undoubtedly provide guidance. However, the change in the quantitative structure of EPL spaces is only one of their characteristics, and analyzing the restructuring process only from this perspective will lead to a biased understanding of regional development issues, which in turn will lead to decisions that are inappropriate for regional development based on the requirements of macro-policies. For example, agricultural land in East Asian countries, which have large populations and limited arable land, is characterized by fragmentation and small-scale family operations. In the process of industrialization and urbanization, agriculture is sidelined, and agricultural workers are aging, which has led to a decline in the efficiency of arable land and an increase in the proportion of abandoned arable land. In this context, Japan, Korea and China have adjusted their policies and laws to promote rural land management to ensure food security and promote large-scale rural land operations. However, the overuse of land area as a measurement standard has led to problems in policy implementation. For example, in Japan, under their policy stipulating the distribution system for rice-cultivation areas, the government has taken compulsory measures to make different regions have the same proportions of rice-production areas, which has harmed the interests of some large-scale farmers with higher production efficiency. China's local governments, forced by pressure for arable land protection, strongly dominate rural-spatial restructuring. However, they focus only on increasing arable land area, leading to the opening of sloping fields, fencing of lakes and land reclamation, resulting in new conflicts in the relationship between people and land. Given social and economic changes and innovations, it is difficult to adequately study rural-spatial restructuring in the context of the relationship between people and land by focusing only on the quantitative and spatial structural characteristics of land-use patterns $[40,41]$. Therefore, we examined rural-spatial restructuring based on land-use transformation via two aspects: quantitative changes and qualitative changes. The quantitative aspect manifests mainly in explicit morphological changes in land use, i.e., changes in the data and spatial patterns of land use. The qualitative aspect manifests as changes in implicit land-use patterns, especially in the evaluation of systemic functions [42]. 
Accordingly, this paper proposes a hypothesis of rural-spatial restructuring based on the evaluation of EPL spaces in terms of the changes in the dominant and recessive morphologies of land use, using Zhulin Town of Henan Province as an example. The objectives of this paper were as follows: (1) to analyze the changes in the dominant morphology of land use by identifying the distribution characteristics of the elements of EPL spaces and analyzing the structural changes in EPL spaces over the past 30 years; (2) to construct a framework for objectively evaluating the functional suitability of EPL spaces in different periods, starting from the natural background constraints and socioeconomic development incentives, to characterize the changes in the recessive morphology of land use; and (3) to combine the distribution and structural changes in EPL spaces with their functional suitability in different periods to determine any relations between them in order to judge the process of rural-spatial restructuring and lay a solid foundation for the next step in rural revitalization.

\section{Materials and Methods}

\subsection{Study Area}

Zhulin is located in the central region of China, Henan Province, in the transition zone between mountains and hills, with National Highway 310 passing through the territory (Figure 1). Originally an administrative village, Zhulin was established as a town in 1994 and became the first all-resident town in Henan Province in 2010, when all villages under its jurisdiction were converted into neighborhood committees (In China's rural areas, towns and administrative villages are two different administrative levels, and villages are subordinate to towns. The neighborhood committees are the smallest administrative units of the city, and their administrative level is the same as that of the village. The change from village to neighborhood community means that the people in Zhulin have changed from villagers to urban residents). After several large-scale zoning adjustments in 1994, 2006 and 2012, the town now has a total area of about $20 \mathrm{~km}^{2}$. In 2019, the town had a resident population of 21,000, total social output value of CNY 10 billion, tax revenue of CNY 300 million and per capita income of CNY 40,300.

Following the past 40 years of reform and opening up, Zhulin is one of the few inland mountain villages to have evolved from a small village with no industry and far from any city to a modern town with a focus on industrial and tourism development. It is also a pilot town for sustainable development in China established by the UNDP and has won the Dubai International Award for the Best Practice in Improving the Living Environment, established by UN-Habitat. Thus, the rural restructuring of Zhulin can be regarded as a condensed version of China's rural development, and the restructuring trajectory of Zhulin from an inland agricultural village to a modern town makes it a perfect model for study. There is an element of chance in Zhulin's development process, as the direction of development of any geographic system cannot be purely inevitable, and an element of chance is understandable [43]; rural territorial systems are no exception. A study of the spatial restructuring history of Zhulin to determine the objective factors regarding the chance and necessity in its development process is of strong significance for guiding the development of other villages. 


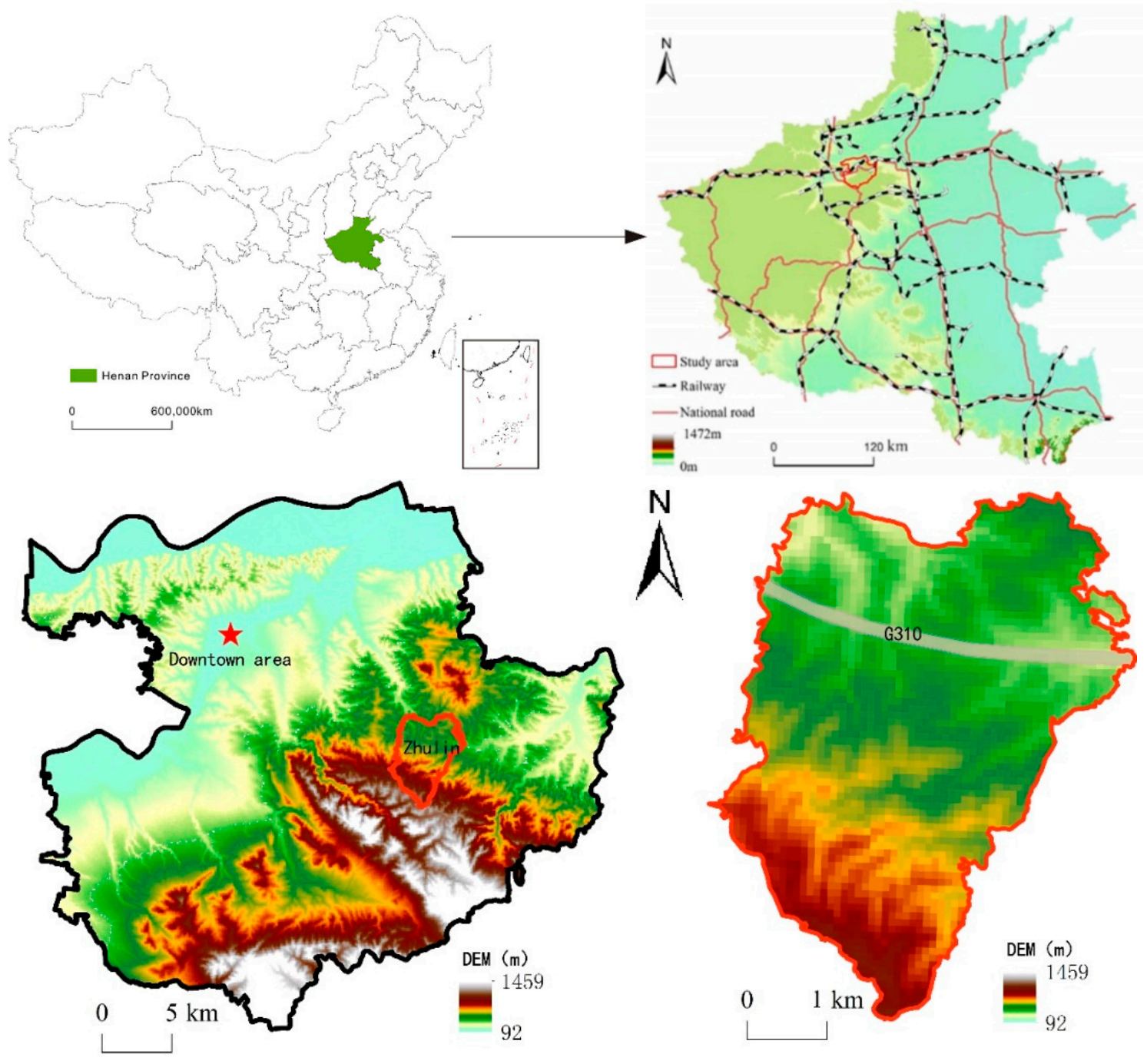

Figure 1. Zhulin location and topographic map (2018).

\subsection{Data Source}

It is difficult to obtain land-use data for long-term series at the village and township levels, and our land-use data come from a survey of Zhulin initiated in 2016. Additional land-use data from 1990 and 1995 were obtained by digitizing hand-drawn maps in village files and spatially matching important markers. A map from the end of 2005 was obtained from the current land-use map provided by the land department, and the maps for the ends of 2010 and 2018 were obtained from the current land-use map of the general plan of Zhulin prepared in those years. On this basis, through in-depth research, old village cadres, retired government or enterprise managers of the village, and current town leaders who had experienced Zhulin's complete development cycle were asked to assist in conducting participatory assessment surveys and record the time points of construction and changes in important surface structures, roads and facility sites to calibrate and match the above base maps by inverting the land-use situation over the historical period. Furthermore, the elevation, slope and other related data used in the functional suitability analysis were extracted from $30 \mathrm{~m}$-precision TM remote-sensing data provided by the National Science and Technology Infrastructure Platform, National Earth System Scientific Data Sharing Platform, Lower Yellow River Scientific Data Center. Data on the multiyear average vegetation net primary productivity, multiyear average precipitation, multiyear average temperatures, soil infiltration factors, rainfall erosion forces, and conditions for accumulated temperatures, and the NDVI vegetation index dataset involved in the ecolog- 
ical suitability analysis were obtained using the Resource and Environment Data Cloud Platform of the Chinese Academy of Sciences and calculated using relevant conversion formulas. The soil physicochemistry-related data were mainly obtained from the Chinese Soil Dataset V1.1 based on the Harmonized World Soil Database (HWSD) of the Cold and Arid Regions Science Data Center. Data on forest park and ecological reserve delineation were obtained from information provided by the Natural Resources and Planning Bureau of Gongyi City. Data related to agricultural water supply facilities and major agricultural infrastructure were provided by the Agriculture and Rural Bureau of Gongyi City. Data on geological hazard susceptibility assessment came from the assessment in the Thirteenth Five-Year Plan for Geological Hazards of Gongyi City.

\subsection{Research Methods}

\subsubsection{Identification and Classification of EPL Spaces}

In addition to the natural properties of land, the classification of EPL spaces should be based on the subjective land-use intentions of the actors [22]. Among these, production space refers to a land-use system that provides a material space carrier for human production and business activities [44]. Living space is a land-use system that carries and protects human residential life and social activities. Ecological space is a land-use system that regulates, maintains and protects ecological security functions [45]. There are two common models for identifying and classifying EPL spaces. One is the index system measurement method, which classifies EPL spaces mainly by establishing a comprehensive evaluation index system [46]. Due to data availability, this method is studied mainly at the medium and macro scales, such as cities and counties (districts). Another method is spatial merging based on land-use type, i.e., merging and reclassifying land-use types according to the dominant functions of the land [47]. For the relatively micro village and township scales, the latter method can quickly identify the spatial distribution of land-use spaces and reflect the functions of land from the perspective of land-use structure. Accordingly, this paper took the land-use classification standards of the People's Republic of China Current Land Use Classification (GB/T21010-2017) and Standard for Planning of Town (GB50188-2007) as a basis and, together with actual land-use patterns in Zhulin, identified the quantity and distribution of EPL spaces in Zhulin. In particular, note that production space carries human production activities and contains primary industry land, secondary industry land and tertiary industry land. Primary industry land can also be agricultural-production space, the main form of rural production space in the early stage of development, while secondary and tertiary industry land can also be nonagricultural-production space, which gradually emerges in the countryside only after industrialization and urbanization [20], which have clear distinctions in terms of land type and functional suitability [47]. Therefore, production space is further classified into agricultural-production space and nonagricultural-production space (Table 1). 
Table 1. Classification of ecological-production-living spaces.

\begin{tabular}{|c|c|c|}
\hline $\begin{array}{l}\text { Ecological-Production-Living } \\
\text { Space Classification }\end{array}$ & Level 1 Land-Use Type & Level 2 Land-Use Type \\
\hline \multirow[b]{2}{*}{ Ecological space } & Green space & $\begin{array}{l}\text { Public green space } \\
\text { Protected green space }\end{array}$ \\
\hline & Water and other land & $\begin{array}{c}\text { Water } \\
\text { Forest land in agricultural and forestry land } \\
\text { Unused land } \\
\text { Pasture for grazing }\end{array}$ \\
\hline \multirow{2}{*}{ Agricultural-production space } & Production facility land & Land for agricultural-production services \\
\hline & Land for agriculture and forestry & Arable land, vegetable land, garden land, nursery \\
\hline \multirow{3}{*}{ Nonagricultural-production space } & Production facility land & $\begin{array}{l}\text { Class } 1 \text { industrial land } \\
\text { Class } 2 \text { industrial land } \\
\text { Class } 3 \text { industrial land }\end{array}$ \\
\hline & Land for storage facilities & $\begin{array}{l}\text { Land for general storage } \\
\text { Land for storing hazardous materials }\end{array}$ \\
\hline & Land for public facilities & $\begin{array}{l}\text { Commercial and financial land } \\
\text { Market land }\end{array}$ \\
\hline \multirow{4}{*}{ Living space } & Land for residential facilities & $\begin{array}{l}\text { Class } 1 \text { residential land } \\
\text { Class } 2 \text { residential land }\end{array}$ \\
\hline & Land for public facilities & $\begin{array}{c}\text { Land for administration } \\
\text { Land for educational institutions } \\
\text { Land for culture, sports and technology } \\
\text { Land for healthcare }\end{array}$ \\
\hline & External transportation land & $\begin{array}{l}\text { Land for highways } \\
\text { Land for other transportation }\end{array}$ \\
\hline & Engineering facilities land & $\begin{array}{c}\text { Land for public engineering } \\
\text { Land for sanitation facilities } \\
\text { Land for disaster prevention facilities }\end{array}$ \\
\hline
\end{tabular}

\subsubsection{Evaluation Index System for Functional Suitability of EPL Spaces}

The functional suitability of land refers to its degree of suitability for a particular use within a range under certain conditions [48], and the suitability evaluation of land function is essentially a concept formed by the interaction between the natural environment and the human social system; the exploration of its theoretical connotations returns to the theory of the territorial system of human-land interaction itself to find its basis [49]. Therefore, based on the concept of land function suitability evaluation, the suitability evaluation of EPL spaces can be defined as the suitability of land for production, living and ecological functions in a specific range under specific conditions [50]. Specifically, the evaluation of the functional suitability of EPL spaces should ultimately return to the service of human development, which includes three aspects [51]. (1) It must ensure the safety of the ecological environment base, which is the basis of human survival, requiring the development activities and scale to be coordinated with the carrying capacity of regional resources and the environment, maintaining surface ecosystem service functions, and emphasizing the protection of important ecosystems. (2) It must ensure the safety of human society. Urbanization and industrial development should occur in areas with stable and good natural conditions to ensure human security and avoid using built-up land in disaster risk areas. (3) It must provide certain economic benefits. From the perspective of human society, land function needs to meet the laws of spatial economy, requiring the siting of construction to consider the impact of land conditions on engineering costs, while facilitating the external linkage of people and socioeconomic activities carried out in the construction space and making socioeconomic services easily accessible. Factors (1) and (2) can be regarded as 
constraining conditions based on the natural background, while factor (3) can be regarded as an incentive condition in line with the laws of socioeconomic development. Accordingly, we took the natural background as the constraining condition and the factors that are conducive to economic and social development as the incentive condition to establish a corresponding index system based on the actual situation of the case study area and data availability. We then comprehensively evaluated the functional suitability of the EPL spaces based on these two aspects. The spatial suitability evaluation of individual factors under the three functions of ecology, production and living was performed based on five levels: suitable, moderately suitable, average, moderately unsuitable, and unsuitable; the weights were finally determined through expert consultation and an AHP (analytical hierarchy process) (Eight experts in related fields scored the evaluation system. Three experts in the first round of scoring could not pass the logical consistency test, so three more experts were invited for the second scoring evaluation. The evaluation matrix was established based on the scores, in which the ecological space judgment matrix $\lambda$ max was 5.4451 , with a CR value of $0.0994<0.1$; the agricultural-production space judgment matrix $\lambda \max$ was 6.2079 , with a $C R$ value of $0.0330<0.1$; the nonagricultural-production space judgment matrix $\lambda \max$ was 6.2593 , with a $C R$ value of $0.0412<0.1$; and the living space judgment matrix $\lambda$ max was 6.1689 , with a $C R$ value of $0.0268<0.1$, all of which passed the consistency test). After rasterizing the evaluation indexes, $100 \times 100 \mathrm{~m}$ raster cells were used as the basic evaluation units, and the ArcGIS spatial analysis function was used for weighted superposition. The weighted summation method of factor scores was adopted to obtain comprehensive evaluation scores of the spatial suitability of the EPL spaces. The calculation formula was:

$$
S_{i}=\sum_{j}^{n} w_{i j} V_{i j}=\left\{S_{1}, S_{2}, S_{3}, S_{4}\right\}
$$

$\left\{S_{1}, S_{2}, S_{3}, S_{4}, S_{5}\right\}=\{$ suitable, moderately suitable, average, moderately unsuitable, unsuitable, respectively $\}=\{(5,4),[4,3),[3,2),[2,1),[1,0)\}$, where $S_{i}$ is the functional suitability evaluation value of class $i$ space in the EPL spaces (the larger the value, the higher the suitability of the corresponding space); $w_{i j}$ and $V_{i j}$ are the weight and role score of the $j$ th factor in class $i$ space, respectively; and $n$ is the total number of influencing factors.

\section{Evaluation of the functional suitability of ecological space}

The constraining factors include the biodiversity-maintenance function, water-conservation function, soil-and-water-conservation function and vegetation cover. The biodiversitymaintenance function is the role played by ecosystems in maintaining genetic, species and ecosystem variability, and is one of the most important functions provided by ecosystems. The water-conservation function is an important part of the ecological space function, which is a direct manifestation of the interaction between vegetation and water in the field of ecological services and an important function in meeting human water demand. The soil-and-water-conservation function is also an important part of the ecological space function, and is conducive to the full use of the economic and social benefits of soil and water resources, reducing flood and drought disasters, and establishing a good ecological environment. We adopted these three indicators through comprehensive evaluation of the variables, including the multiyear mean vegetation net primary productivity, multiyear average precipitation, multiyear average temperature, soil infiltration factor, rainfall erosion force and soil erodibility, as collected from the Resource and Environment Data Cloud Platform of the Chinese Academy of Sciences. Other variables, including the elevation, slope and slope direction ere obtained from digital elevation model (DEM) data analysis. The indicators were evaluated in a hierarchical manner according to the number of accumulated service functions in the evaluation results. The calculation basis for these three indicators was as follows: 
Biodiversity-maintenance function:

$$
V_{\text {bio }}=N P P_{\text {mean }} \times F_{\text {pre }} \times F_{\text {tem }} \times\left(1-F_{\text {ele }}\right)
$$

where $V_{b i o}$ is the value of the biodiversity-maintenance function, $N P P_{\text {mean }}$ is the multiyear mean vegetation net primary productivity, $F_{\text {pre }}$ is the multiyear average precipitation factor, $F_{t e m}$ is the multiyear average temperature factor, and $F_{e l e}$ is the elevation factor.

Water-conservation function:

$$
V_{\text {wr }}=N P P_{\text {mean }} \times F_{\text {sic }} \times F_{\text {pre }} \times\left(1-F_{\text {slo }}\right)
$$

where $V_{w r}$ is the value of the water-conservation function, $N P P_{\text {mean }}$ is the multiyear mean vegetation net primary productivity, $F_{s i c}$ is the soil infiltration factor, $F_{p r e}$ is the multiyear average precipitation factor, and $F_{s l o}$ is the slope factor.

Soil-and-water-conservation function:

$$
V_{s w}=N P P_{\text {mean }} \times(1-K) \times\left(1-F_{\text {slo }}\right)
$$

where $V_{s w}$ is the value of the soil-and-water-conservation function, $N P P_{\text {mean }}$ is the multiyear mean vegetation net primary productivity, $K$ is the soil erodibility factor, and $F_{s l o}$ is the slope factor.

Vegetation is the primary component and functional body of the ecosystem, and the study of the spatiotemporal characteristics of the fraction of vegetation cover (FCV) is the basis for evaluating ecological spatial quality. The annual NDVI vegetation index dataset for the period of 1990-2018 was obtained using the Resource and Environment Data Cloud Platform of the Chinese Academy of Sciences. There is a significant linear correlation between vegetation cover and the NDVI, and vegetation cover information is usually extracted directly by establishing the conversion relationship between the two [52]. The multiyear average vegetation cover of the study area was obtained using the pixel dichotomy method $[53,54]$, and the evaluation was performed according to vegetation cover.

The incentive factors are mainly ecological control factors, namely, the three protection facility systems established in situ nationwide, including nature reserves, forest parks and scenic spots. Nature reserves are mainly for absolute protection, and forest parks and scenic spots are for both protection and development. The suitability of the ecological spatial incentive factors was evaluated hierarchically according to whether they belonged

\begin{tabular}{|c|c|c|c|c|c|c|c|c|}
\hline Target Layer & Criterial Layer & Index Layer & Suitable & $\begin{array}{l}\text { Moderately } \\
\text { Suitable }\end{array}$ & Average & $\begin{array}{l}\text { Moderately } \\
\text { Unsuitable }\end{array}$ & Unsuitable & Weight \\
\hline \multirow{5}{*}{$\begin{array}{l}\text { Evaluation of } \\
\text { functional } \\
\text { suitability of } \\
\text { live space }\end{array}$} & \multirow{4}{*}{$\begin{array}{l}\text { Constraining } \\
\text { factors }\end{array}$} & $\begin{array}{l}\text { Biodiversity- } \\
\text { maintenance } \\
\text { function }\end{array}$ & $\begin{array}{c}\text { Top } 30 \% \text { of } \\
\text { cumulative service } \\
\text { function volume }\end{array}$ & Top $30-50 \%$ & Top 50-70\% & Top $70-85 \%$ & Below top $85 \%$ & 0.3398 \\
\hline & & $\begin{array}{l}\text { Water- } \\
\text { conservation } \\
\text { function }\end{array}$ & $\begin{array}{c}\text { Top } 30 \% \text { of } \\
\text { cumulative service } \\
\text { function volume }\end{array}$ & Top 30-50\% & Top 50-70\% & Top 70-85\% & Below top $8 \%$ & 0.3319 \\
\hline & & $\begin{array}{l}\text { Soil-and- } \\
\text { water- } \\
\text { conservation } \\
\text { function }\end{array}$ & $\begin{array}{l}\text { Top } 30 \% \text { of } \\
\text { cumulative service } \\
\text { function volume }\end{array}$ & Top 30-50\% & Top 50-70\% & Top 70-85\% & Below 85\% & 0.1567 \\
\hline & & $\begin{array}{l}\text { Fraction of } \\
\text { vegetation } \\
\text { cover }\end{array}$ & $0.7<\mathrm{FVC} \leq 1$ & $\begin{array}{c}0.5<\mathrm{FVC} \leq \\
0.7\end{array}$ & $\begin{array}{c}0.3<\mathrm{FVC} \leq \\
0.5\end{array}$ & $0.1<\mathrm{FVC} \leq 0.3$ & $\mathrm{FVC} \leq 0.1$ & 0.1010 \\
\hline & $\begin{array}{l}\text { Incentive } \\
\text { factors }\end{array}$ & $\begin{array}{c}\text { Ecological } \\
\text { control factors }\end{array}$ & $\begin{array}{l}\text { National nature } \\
\text { reserve }\end{array}$ & $\begin{array}{l}\text { Provincial } \\
\text { nature reserve }\end{array}$ & $\begin{array}{c}\text { National forest } \\
\text { park/scenic } \\
\text { spot }\end{array}$ & $\begin{array}{l}\text { Provincial forest } \\
\text { park/scenic spot }\end{array}$ & $\begin{array}{c}\text { Local } \\
\text { protection } \\
\text { facilities }\end{array}$ & 0.0706 \\
\hline
\end{tabular}
to these three systems (Table 2).

Table 2. Evaluation of functional suitability of ecological space.

2. Evaluation of the functional suitability of agricultural-production space

The constraining factors include the slope, soil texture, agricultural water supply conditions and light and heat conditions. The slope affects the water and fertilizer uptake 
by crops, along with the light conditions for crops. In addition, the greater the slope, the more likely it is that agricultural activities will cause soil erosion. Soil texture is one of the physical properties of soil and is closely related to the conditions of soil aeration, fertilizer and water retention, and ease of cultivation. Agricultural water is the most basic condition for agricultural production. Light and heat conditions affect the distribution of crop species, the replanting system, and yield. Accordingly, this distribution is based on the slope, soil texture, average rainfall and surface water supply over time; the elevation-corrected active accumulated temperature of the multiyear average daily temperature $\geq 0{ }^{\circ} \mathrm{C}$ serves as the evaluation index. According to the grade evaluation from the Technical Regulations of Land Use Status Survey issued by the China Agricultural Zoning Commission and China's National Standard Cultivated Land Quality Grade (GB/T 33469-2016) for the slope, soil type, water supply conditions and temperature accumulation conditions, the classification was performed according to the actual situation of the case study area, and we evaluated the suitability of the spatial constraining factors of the agricultural-production space.

The incentive factors include, mainly, the cultivation radius and distance to major agricultural facilities. The quality of agricultural-production space is related not only to natural endowments, but also to human-made factor inputs. Under equal conditions, the closer the arable land is to a settlement, the greater the ease of cultivation and the higher the suitability in comparison. Major agricultural facilities can greatly increase the efficiency of land-based production, improve the utilization of resources and labor productivity, and thus increase the efficiency, quality and competitiveness of agriculture. Therefore, the suitability of the agricultural-production space was evaluated by the nearest distance method according to the distance from settlements. It was also evaluated hierarchically using the Jenks natural-breaks classification method. The suitability of the incentive factors for the agricultural-production space were obtained by evaluation using buffer analysis according to the distance from major agricultural facilities (Table 3).

Table 3. Evaluation of functional suitability of agricultural-production space.

\begin{tabular}{|c|c|c|c|c|c|c|c|c|}
\hline Target Layer & Criteria Layer & Index Layer & Suitable & $\begin{array}{l}\text { Moderately } \\
\text { Suitable }\end{array}$ & Average & $\begin{array}{l}\text { Moderately } \\
\text { Unsuitable }\end{array}$ & Unsuitable & Weight \\
\hline \multirow{6}{*}{$\begin{array}{l}\text { Evaluation of } \\
\text { functional } \\
\text { suitability of } \\
\text { agricultural } \\
\text { space }\end{array}$} & \multirow{4}{*}{$\begin{array}{l}\text { Constraining } \\
\text { factors }\end{array}$} & Gradient & $0^{\circ}-2^{\circ}$ & $2^{\circ}-6^{\circ}$ & $6^{\circ}-15^{\circ}$ & $15^{\circ}-25^{\circ}$ & Above $25^{\circ}$ & 0.2293 \\
\hline & & Soil texture & Loam soil & $\begin{array}{c}\text { Clay loam soil, } \\
\text { powdered clay } \\
\text { loam, sandy } \\
\text { clay loam }\end{array}$ & $\begin{array}{l}\text { Powdered clay, } \\
\text { sandy clay, } \\
\text { sandy loam, } \\
\text { powdered } \\
\text { loam }\end{array}$ & $\begin{array}{l}\text { Loamy sandy } \\
\text { soil, clay }\end{array}$ & $\begin{array}{l}\text { Sandy soil, } \\
\text { chalky soil }\end{array}$ & 0.2278 \\
\hline & & $\begin{array}{l}\text { Agricultural water } \\
\text { supply conditions }\end{array}$ & Fully satisfied & Satisfied & $\begin{array}{l}\text { Basically } \\
\text { satisfied }\end{array}$ & $\begin{array}{l}\text { Inadequately } \\
\text { satisfied }\end{array}$ & Unsatisfied & 0.3032 \\
\hline & & $\begin{array}{l}\text { Light and heat } \\
\text { conditions }\end{array}$ & Above 4500 & $3400-4500$ & $1600-3400$ & $\mathrm{~N} / \mathrm{A}$ & $\mathrm{N} / \mathrm{A}$ & 0.0943 \\
\hline & \multirow{2}{*}{$\begin{array}{l}\text { Incentive } \\
\text { factors }\end{array}$} & Farming radius & Within 40.63 & $40.63-126.76$ & $126.76-255.26$ & $255.26-427.79$ & Above 427.79 & 0.0665 \\
\hline & & $\begin{array}{l}\text { Distance to major } \\
\text { agricultural facilities }\end{array}$ & $500 \mathrm{~m}$ & 500-1000 m & $1000-1500 \mathrm{~m}$ & 1500-2000 m & Above $2000 \mathrm{~m}$ & 0.0790 \\
\hline
\end{tabular}

3. Evaluation of the functional suitability of nonagricultural-production space

The constraining factors include the slope, elevation, topographical relief and geological conditions. Nonagricultural-production space is mainly urban built-up land, and the slope has a strong impact on this space. Engineering construction costs increase with increased terrain slopes, and steep terrain is prone to geological phenomena such as landslides and mudslides. Elevation is an important factor affecting land for urban and rural construction; low-elevation areas are generally more suitable for human habitation than high-elevation areas, and the suitability for human habitation decreases with increasing elevation [55]. Topographic relief refers to the difference between the elevation of the highest point and the elevation of the lowest point in a specific area, and to a certain extent, it reflects the difficulty of engineering construction. The stability of engineering geological conditions is the basis of site selection for nonagricultural-production space. Thus, according to the slope classification standard for industrial land selection of the National Standard 
Code for Vertical Planning on Urban and Rural Development Land (CJJ 83-2016) of the People's Republic of China, and the altitude of elevation, we calculated the topographical relief and regional geological hazard susceptibility using grids $(30 \times 30 \mathrm{~m}$ grid cells $)$ and evaluated the suitability of the constraining factors for nonagricultural-production space in the context of the local situation.

The incentive factors include, mainly, industrial agglomeration and convenient transportation. Rural nonagricultural industries include, mainly, the secondary industry, the production-support service industry, the living service industry to meet residents' consumption demand and the tourism industry. Due to external economies and diseconomies, industrial agglomeration develops from the relative concentration of industrial and commercial enterprises in geographic and spatial locations, bringing corresponding costs and benefits to enterprises, and thus further influencing the spatial layout of industries. Therefore, we used the hot-spot analysis method in ArcGIS to determine the hot and cold spots through the distribution of natural break points and the influence of the industrial agglomeration effect on the industrial layout. Based on the distance from traffic arteries, we used the buffer analysis in ArcGIS to evaluate the transportation convenience. Different levels of buffer were established according to the levels of national roads, provincial roads, county roads and township roads to determine traffic convenience; this was used to evaluate the suitability of the incentive factors for nonagricultural-production space (Table 4).

Table 4. Evaluation of functional suitability of nonagricultural-production space.

\begin{tabular}{|c|c|c|c|c|c|c|c|c|}
\hline Target Layer & Criteria Layer & Index Layer & Suitable & $\begin{array}{l}\text { Moderately } \\
\text { Suitable }\end{array}$ & Average & $\begin{array}{l}\text { Moderately } \\
\text { Unsuitable }\end{array}$ & Unsuitable & Weight \\
\hline \multirow{6}{*}{$\begin{array}{l}\text { Evaluation of } \\
\text { functional } \\
\text { suitability of } \\
\text { nonagricul- } \\
\text { tural } \\
\text { space }\end{array}$} & \multirow{4}{*}{$\begin{array}{l}\text { Constraining } \\
\text { factors }\end{array}$} & Gradient & $0^{\circ}-5^{\circ}$ & $5^{\circ}-8^{\circ}$ & $8^{\circ}-15^{\circ}$ & $15^{\circ}-25^{\circ}$ & Above $25^{\circ}$ & 0.1174 \\
\hline & & Elevation & Under $200 \mathrm{~m}$ & $200-300 \mathrm{~m}$ & $300-500 \mathrm{~m}$ & $500-1000 \mathrm{~m}$ & Above $1000 \mathrm{~m}$ & 0.0528 \\
\hline & & Topographical relief & $0-50$ & 50-100 & $100-150$ & $150-200$ & Above 200 & 0.0621 \\
\hline & & Geological conditions & $\begin{array}{c}\text { No } \\
\text { susceptibility }\end{array}$ & $\begin{array}{c}\text { Low } \\
\text { susceptibility }\end{array}$ & $\begin{array}{c}\text { Medium } \\
\text { susceptibility }\end{array}$ & $\begin{array}{c}\text { High } \\
\text { susceptibility }\end{array}$ & $\begin{array}{c}\text { Extreme } \\
\text { susceptibility }\end{array}$ & 0.0526 \\
\hline & \multirow{2}{*}{$\begin{array}{l}\text { Incentive } \\
\text { factors }\end{array}$} & $\begin{array}{c}\text { Industrial } \\
\text { agglomeration }\end{array}$ & Hot spots & Sub-hot spots & Mild spots & Sub-cold spots & Cold spots & 0.3999 \\
\hline & & $\begin{array}{c}\text { Transportation } \\
\text { convenience }\end{array}$ & Convenient & $\begin{array}{l}\text { Moderately } \\
\text { convenient }\end{array}$ & Average & $\begin{array}{c}\text { Moderately } \\
\text { inconvenient }\end{array}$ & Inconvenient & 0.3152 \\
\hline
\end{tabular}

4. Evaluation of the functional suitability of living space

Living space also belongs to the category of urban built-up land, and its constraining conditions are similar to those of nonagricultural-production space, including four factors: the slope, elevation, topographical relief and geological conditions. The slope conditions were evaluated for their functional suitability according to the slope-grading criteria for urban and rural residential land selection in the National Standard of the People's Republic of China Code for Vertical Planning on Urban and Rural Development Land (CJJ 83-2016). Since the elevation, topographic relief and engineering geology were judged on the same basis as nonagricultural-production space, they will not be described separately.

The incentive factors include, mainly, living convenience and transportation. In addition to the function of living, corresponding social activities and social functions are essential for meeting the daily living needs of human beings. Therefore, using the buffer analysis method in ArcGIS, and based on the delineation of the community's 15 min living circle, buffer zones with radii of 350, 700 and $1000 \mathrm{~m}$ were established, with the village and town administrative service center, hospitals, schools and cultural and sports facilities serving as the center for comprehensively evaluating the spatial living convenience. This resulted in five classification levels: convenient, moderately convenient, average, moderately inconvenient and inconvenient. Since the evaluation criteria for transportation convenience were the same as those for nonagricultural-production space, they are not described separately (Table 5). 
Table 5. Evaluation of functional suitability of living space.

\begin{tabular}{|c|c|c|c|c|c|c|c|c|}
\hline Target Layer & Criteria Layer & Index Layer & Suitable & $\begin{array}{l}\text { Moderately } \\
\text { Suitable }\end{array}$ & Average & $\begin{array}{l}\text { Moderately } \\
\text { Unsuitable }\end{array}$ & Unsuitable & Weight \\
\hline \multirow{6}{*}{$\begin{array}{l}\text { Evaluation of } \\
\text { functional } \\
\text { suitability of } \\
\text { living space }\end{array}$} & \multirow{4}{*}{$\begin{array}{l}\text { Constraining } \\
\text { factors }\end{array}$} & Gradient & $0^{\circ}-5^{\circ}$ & $5^{\circ}-8^{\circ}$ & $8^{\circ}-20^{\circ}$ & $20^{\circ}-25^{\circ}$ & Above $25^{\circ}$ & 0.1074 \\
\hline & & Elevation & Under 200 & $200-300$ & $300-500$ & $500-1000$ & Above 1000 & 0.0573 \\
\hline & & Topographical relief & $0-50$ & $50-100$ & $100-150$ & $150-200$ & Above 200 & 0.0662 \\
\hline & & Geological conditions & $\begin{array}{c}\text { No } \\
\text { susceptibility }\end{array}$ & $\begin{array}{c}\text { Low } \\
\text { susceptibility }\end{array}$ & $\begin{array}{c}\text { Medium } \\
\text { susceptibility }\end{array}$ & $\begin{array}{c}\text { High } \\
\text { susceptibility }\end{array}$ & $\begin{array}{c}\text { Extreme } \\
\text { susceptibility }\end{array}$ & 0.0449 \\
\hline & \multirow{2}{*}{$\begin{array}{l}\text { Incentive } \\
\text { factors }\end{array}$} & Living convenience & Convenient & $\begin{array}{l}\text { Moderately } \\
\text { convenient }\end{array}$ & Average & $\begin{array}{l}\text { Moderately } \\
\text { inconvenient }\end{array}$ & Inconvenient & 0.4184 \\
\hline & & $\begin{array}{l}\text { Transportation } \\
\text { convenience }\end{array}$ & Convenient & $\begin{array}{l}\text { Moderately } \\
\text { convenient }\end{array}$ & Average & $\begin{array}{l}\text { Moderately } \\
\text { inconvenient }\end{array}$ & Inconvenient & 0.3058 \\
\hline
\end{tabular}

\subsubsection{Evaluation of Match between Distribution and Function of EPL Spaces}

Based on the distribution and changes in the functional suitability of EPL spaces, we established a coordinate system to comprehensively judge the match between structural changes in EPL spaces and their functional suitability to reflect Zhulin's spatial restructuring process. In this coordinate system (Figure 2), the $X$-axis is the change in the area structure of EPL spaces and the $Y$-axis is the change in the functional suitability of EPL spaces. The values of $X$ and $Y$ were calculated by Formulas (5) and (6).

$$
\begin{gathered}
X=\Delta X_{i}(t) / X_{i}(t-\Delta t)=\left[X_{i}(t)-X_{i}(t-\Delta t)\right] / X_{i}(t-\Delta t) . \\
Y=\Delta Y_{i}(t) / Y_{i}(t-\Delta t)=\left[Y_{i}(t)-Y_{i}(t-\Delta t)\right] / Y_{i}(t-\Delta t)
\end{gathered}
$$

where $\Delta X_{i}(t)$ is change in the area structure of EPL spaces; $X_{i}(t)$ is the spatial area of type $i$ in period $t ; X_{i}(t-\Delta t)$ is the spatial area of type $i$ in the last cycle of change in period $t ; \Delta Y_{i}(t)$ is the change in the functional suitability of EPL spaces; $Y_{i}(t)$ is the average functional suitability of space of type $i$ in period $t ; Y_{i}(t-\Delta t)$ is the average functional suitability of space of type $i$ in period $t$ during the last cycle of change in period $t$; and $i=1,2,3,4$ denotes ecological space, agricultural-production space, nonagricultural-production space and living space, respectively.

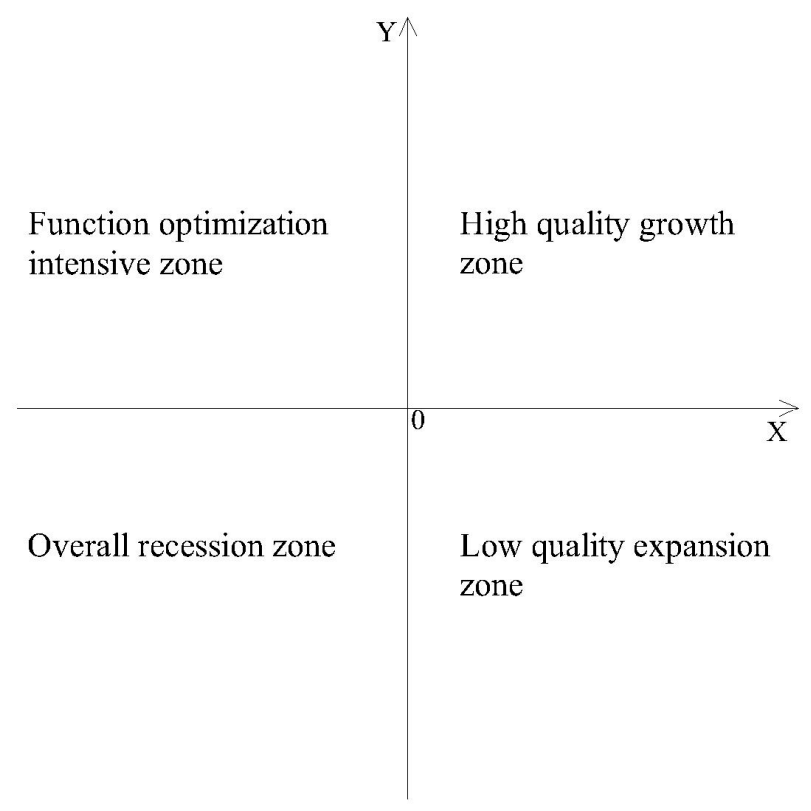

Figure 2. Schematic diagram of spatial distribution and function matching of ecological-productionliving (EPL) spaces.

According to the values of $\mathrm{X}$ and $\mathrm{Y}$, four quadrants are described as follows: 
1. Quadrant I: $\Delta X_{i}(t)>0$ indicates that space of type $i$ has grown, and $\Delta Y_{i}(t)>0$ indicates that the functional suitability of space of type $i$ has improved. This indicates that, along with the growth of space of that type, the functional suitability of space of that type has also improved. Therefore, the first quadrant is a high-quality growth area.

2. Quadrant II: $\Delta X_{i}(t)<0$ indicates that space of type $i$ has decreased, and $\Delta Y_{i}(t)>0$ indicates that the functional suitability of space of type $i$ has improved. This indicates that even with the decrease in the area of space of that type, its functional suitability has improved. Therefore, the second quadrant is the functional optimization intensification area.

3. Quadrant III: $\Delta X_{i}(t)<0$ indicates that space of type $i$ has decreased, and $\Delta Y_{i}(t)<0$ indicates that the functional suitability of space of type $i$ has started to decrease. This indicates that, along with the decrease in the area of space of this type, its functional suitability has decreased. Therefore, the third quadrant is a full-scale decline area.

4. Quadrant IV: $\Delta X_{i}(t)>0$ indicates that space of type $i$ has increased, and $\Delta Y_{i}(t)<0$ indicates that the functional suitability of space of type $i$ has begun to decrease. This indicates that the functional suitability of space of type $i$ decreases with increases in its area. Therefore, the fourth quadrant is a low-quality expansion area.

\section{Results}

3.1. Spatial Distribution and Structural Change of EPL Spaces

3.1.1. EPL Spatial Distribution

Originally a village-level administrative unit, Zhulin was abolished in 1994 and established as a town. It went through several adjustments of administrative divisions and expanded its administrative area from an initial $4.2 \mathrm{~km}^{2}$ to $20.5 \mathrm{~km}^{2}$. The main changes were as follows: (1) In 1994, the village became a town, and the administrative area of Zhulin was expanded from 4.2 to $6.4 \mathrm{~km}^{2}$; (2) in 2006, according to the development requirements of the United Nations Sustainable Development Pilot Town and the opinions of the China Small Town Reform and Development Center of the State Council, the administrative area was further expanded to $16.45 \mathrm{~km}^{2}$; (3) in 2012, to cooperate with the construction of Zhulin Industrial Park and further promote local economic development, the total area of Zhulin was further expanded to $20.5 \mathrm{~km}^{2}$, which is the current administrative division of Zhulin (Figure 3). With the rapid economic and social development of Zhulin and the continuous changes in administrative areas over the decades, the structure of Zhulin's EPL spaces has also changed dramatically. To reflect the distribution structure of its EPL spaces within different administrative boundaries and in different periods of economic and social development, based on data availability, we used 1990 (representing the development period before the establishment of Zhulin Town), 1995 (representing the development period at the beginning of Zhulin Town in 1994), 2005 (representing the development period before the administrative division of Zhulin in 2006), 2010 (representing the development period before Zhulin's administrative division in 2012) and 2018 (representing the development period after Zhulin's administrative division in 2012) as time points to analyze the process of structural changes in Zhulin's EPL spaces. 

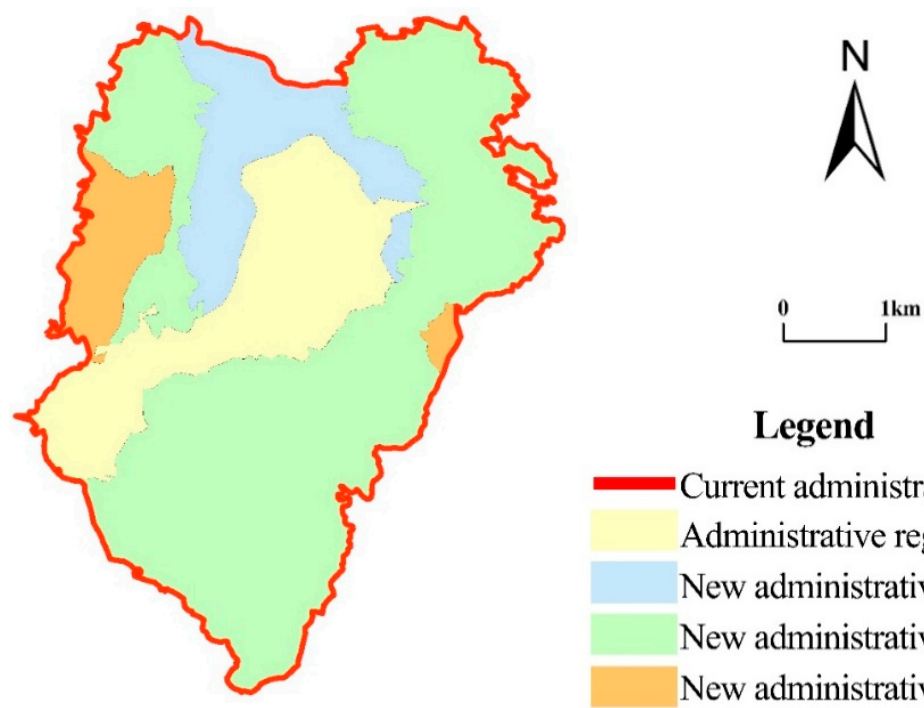

\section{Legend}

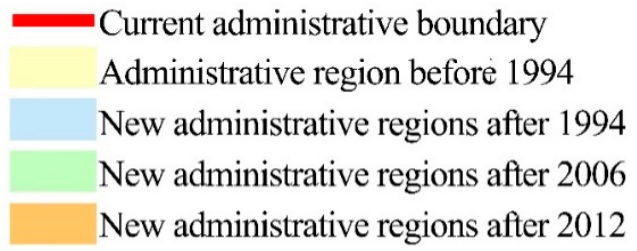

Figure 3. Zhulin administrative area change map.

With the continuous expansion of administrative divisions, the absolute quantity of Zhulin's EPL spaces has grown significantly. From 1990 to 2018, its ecological space grew from 148.26 to $803.46 \mathrm{hm}^{2}$, its agricultural-production space grew from 217.73 to $954.66 \mathrm{hm}^{2}$, its nonagricultural-production space grew from 21.23 to $111.43 \mathrm{hm}^{2}$, and its living space grew from 36.11 to $176.27 \mathrm{hm}^{2}$. The area of ecological space shows some fluctuation, while all the other spaces show a linear growth trend (Table 6).

Table 6. Classification of areas of Zhulin's EPL spaces.

\begin{tabular}{|c|c|c|c|c|c|}
\hline & Ecological Space $\left(\mathrm{hm}^{2}\right)$ & $\begin{array}{l}\text { Agricultural-Production } \\
\text { Space }\left(\mathrm{hm}^{2}\right)\end{array}$ & $\begin{array}{c}\text { Nonagricultural-Production } \\
\text { Space }\left(\mathrm{hm}^{2}\right)\end{array}$ & Living Space $\left(\mathrm{hm}^{2}\right)$ & Total $\left(\mathrm{hm}^{2}\right)$ \\
\hline 1990 & 148.26 & 217.73 & 21.23 & 36.11 & 423.33 \\
\hline 1995 & 271.92 & 292.74 & 24.24 & 52.51 & 641.42 \\
\hline 2005 & 137.79 & 351.47 & 49.22 & 103.41 & 641.89 \\
\hline 2010 & 824.08 & 814.63 & 69.53 & 165.04 & 1873.28 \\
\hline 2018 & 803.46 & 954.66 & 111.43 & 176.27 & 2045.82 \\
\hline
\end{tabular}

The regional characteristics of the spatial distribution of Zhulin's ecological space and agricultural-production space have become increasingly clear. In 1990 and 1995, Zhulin's ecological space was concentrated mainly in the southern mountainous area and the northern region, but its ecological space and agricultural-production space generally showed a cross-distribution (Figure 4a,b). By 2005, the ecological space in the north began to shrink, and the south became the main distribution area of Zhulin's ecological space (Figure 4c). By 2010 and 2018, with the expansion of Zhulin's administrative boundaries, the extent of mountainous areas in the south further increased, while the extent of ecological space in the north further shrank. Eventually, a distribution pattern formed with ecological space dominating in the south and agricultural-production space dominating in the north (Figure $4 \mathrm{~d}, \mathrm{e}$ ). As for living space and nonagricultural-production space, the early living space was concentrated near the main traffic routes, especially on both sides of National Highway 310, but there were also many scattered distributions in the mountainous areas in the south and north. Since 2005, the clustering of living space, in particular, and nonagricultural-production space has strengthened. Many scattered living spaces began to disappear, while the living and nonagricultural-production spaces along the main traffic routes continued to expand. 
(a) 1990

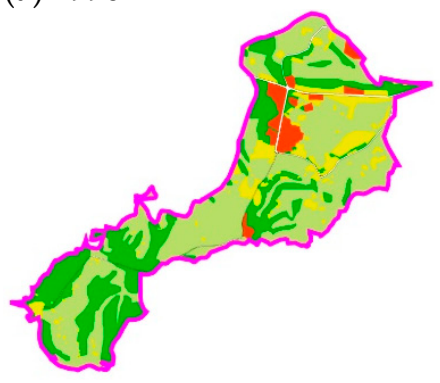

(b) 1995

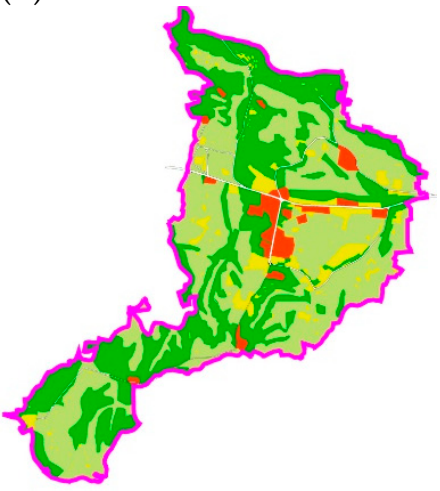

(e) 2018

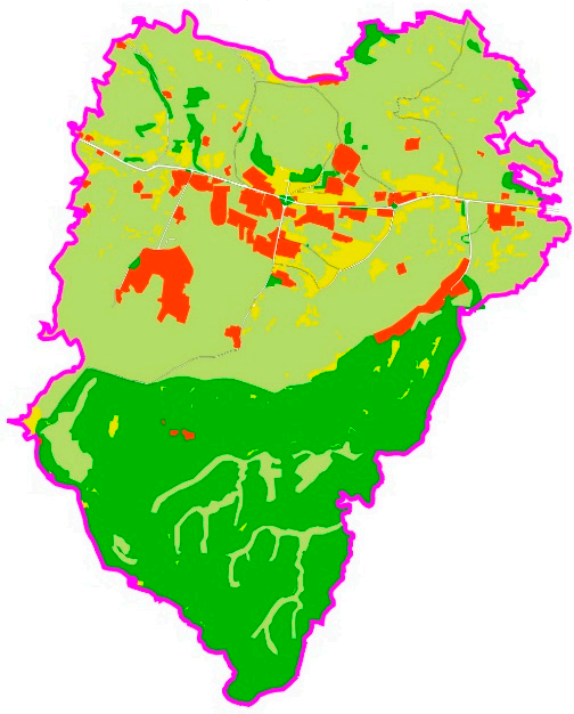

(c) 2005

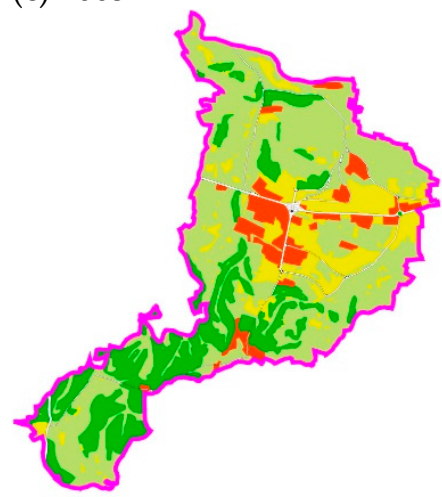

(d) 2010

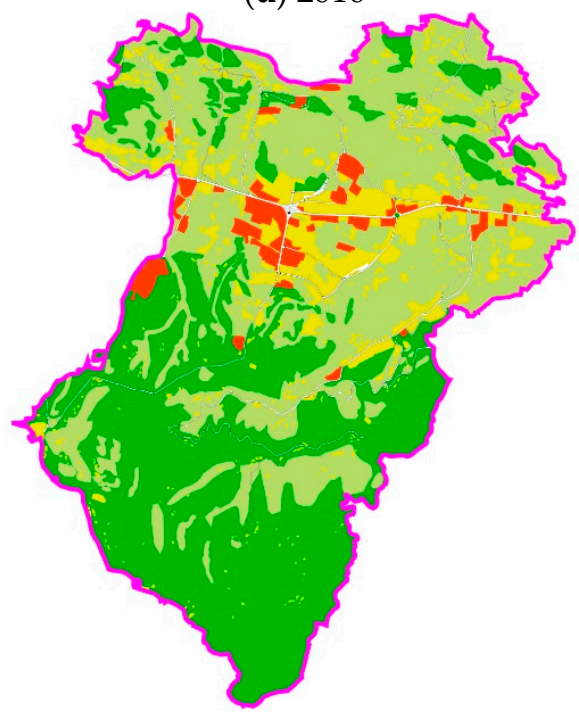

$\mathrm{N}$

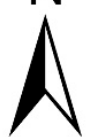

Figure 4. Distribution of Zhulin's EPL spaces, 1990-2018: (a) 1990, (b) 1995, (c) 2005, (d) 2010, (e) 2018.

\subsubsection{Structural Change in EPL Spaces}

In terms of the proportion of EPL spaces, from 1990 to 2018, agricultural-production space and ecological space constituted the largest proportions in Zhulin, with average proportions of $48.40 \%$ and $36.43 \%$, respectively, followed by living space, with an average proportion of $10.05 \%$. Nonagricultural-production space was smallest, with an average proportion of $5.12 \%$. Overall, Zhulin is still dominated by agricultural-production space and ecological space.

From the structural changes in Zhulin's EPL spaces by year (Figure 5), we observe that the proportion of production space (including agricultural-production space and nonagricultural-production space) and living space decreased and then increased, and then decreased and increased again, showing a W-shaped fluctuation curve in general, while the change in the proportion of ecological space shows an opposite pattern to the change in production and living space, showing an M-shaped fluctuation curve. The proportion of production and living space peaked in 2005, when the proportion of ecological space was the lowest; the proportion of ecological space peaked in 2010. 


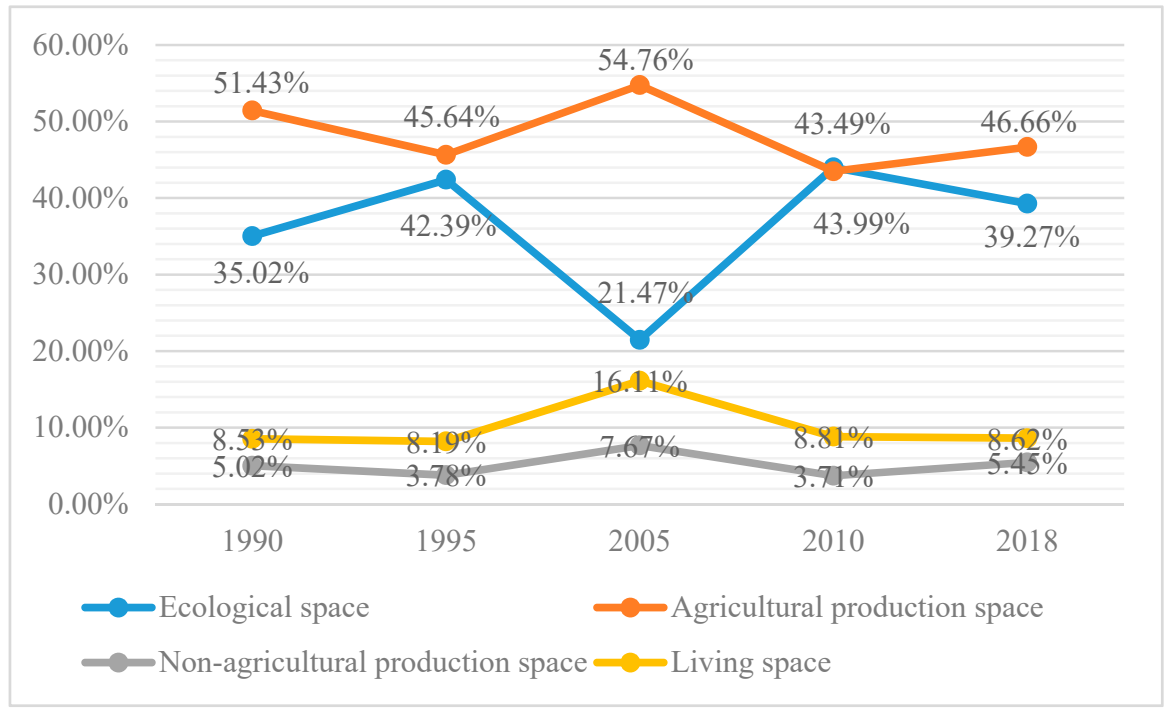

Figure 5. Structural change of Zhulin's EPL spaces.

One reason for this is the change in the area of EPL spaces brought about by the expansion of administrative space. The other reason is that the original EPL spaces have also undergone mutual transformation. In most periods, the increase in the area of EPL spaces was brought about mainly by the increase in administrative boundaries (Table 7). By contrast, the decrease in EPL spaces was mainly due to interconversion among EPL spaces that occurred in different periods (Table 7). From 1990 to 1995, EPL spaces shifted mainly from agricultural-production space to ecological space, nonagricultural-production space and living space. This period was accompanied by decreased agricultural-production space and growth in ecological space, nonagricultural-production space and living space. From 1995 to 2005, EPL spaces were transferred mainly from ecological space to agriculturalproduction space, nonagricultural-production space and living space. From 2005 to 2010, EPL spaces were transferred mainly from agricultural space, nonagricultural space and living space to ecological space. From 2010 to 2018, EPL spaces were transferred mainly from ecological space and living space to nonagricultural-production space and agriculturalproduction space.

Table 7. Changes in areas of Zhulin's EPL spaces.

\begin{tabular}{|c|c|c|c|c|c|c|c|c|c|c|}
\hline \multirow{2}{*}{ Unit: $\mathrm{hm}^{2}$} & \multicolumn{3}{|c|}{ 1990-1995 } & \multirow{2}{*}{$\begin{array}{c}1995-2005^{2} \\
\text { Internal } \\
\text { Changes }\end{array}$} & \multicolumn{3}{|c|}{ 2005-2010 } & \multicolumn{3}{|c|}{$2010-2018$} \\
\hline & Total & $\begin{array}{l}\text { External }^{1} \\
\text { Increase }\end{array}$ & $\begin{array}{l}\text { Internal } \\
\text { Changes }\end{array}$ & & Total & $\begin{array}{l}\text { External } \\
\text { Increase }\end{array}$ & $\begin{array}{l}\text { Internal } \\
\text { Changes }\end{array}$ & Total & $\begin{array}{l}\text { External } \\
\text { Increase }\end{array}$ & $\begin{array}{l}\text { Internal } \\
\text { Changes }\end{array}$ \\
\hline Ecological space & 123.66 & 108.24 & 15.42 & -134.13 & 686.29 & 654.08 & 32.21 & -20.62 & 0.00 & -20.62 \\
\hline $\begin{array}{l}\text { Agricultural- } \\
\text { production } \\
\text { space }\end{array}$ & 75.01 & 96.60 & -21.59 & 58.73 & 463.16 & 495.89 & -32.73 & 140.03 & 124.78 & 15.25 \\
\hline $\begin{array}{l}\text { Nonagricultural- } \\
\text { production } \\
\text { space }\end{array}$ & 3.01 & 2.73 & 0.28 & 24.98 & 20.31 & 22.31 & -2.00 & 41.90 & 3.27 & 38.63 \\
\hline Living space & 16.40 & 11.04 & 5.36 & 50.90 & 61.63 & 62.33 & -0.70 & 11.23 & 65.33 & -54.10 \\
\hline Total & 218.09 & 218.61 & -0.52 & 0.47 & 1231.39 & 1234.61 & -3.22 & 172.54 & 193.38 & -20.84 \\
\hline
\end{tabular}

${ }^{1}$ External increase refers to new areas of various types of land due to expansion of the administrative division, and internal change refers to change in the areas of EPL spaces in the same area as the previous administrative area. ${ }^{2}$. The size of the administrative area in 2005 was the same as that in 1995, so there was no external or internal change.

\subsection{Evaluation of Functional Suitability of EPL Spaces}

\subsubsection{Changes in Functional Suitability of Ecological Space}

An improvement in the functional suitability of the ecological space is clear. In general, our evaluation shows that the functional suitability of Zhulin's ecological spaces deteriorated first and then improved continuously. The mean value of the ecological 
space suitability evaluation decreased from 1.81 to 1.59 , and then continued to rise to 3.52. That means the overall suitability increased from moderately unsuitable, represented by values of (1-2] to moderately suitable, represented by values of (3-4] (Table 8 ). In terms of intragroup variation, the maximum value of the ecological space suitability evaluation showed a large change, while the minimum value remained relatively stable and unchanged. The standard deviations of the indicators ranged from 0.51 to 0.98 , showing a general trend of gradual increase, indicating that the differences between samples gradually increased. The main reason for this is that the proportion of areas evaluated as moderately unsuitable for the functional suitability of ecological space gradually decreased, while the proportion of areas evaluated as average, moderately suitable or suitable gradually increased (Figure 6).

Table 8. Overall evaluation of functional suitability of ecological space.

\begin{tabular}{ccccc}
\hline Year & Max. & Min. & Mean & Standard Deviation \\
\hline 1990 & 2.67 & 1.13 & 1.81 & 0.51 \\
1995 & 2.67 & 1.13 & 1.59 & 0.46 \\
2005 & 2.67 & 1.13 & 1.76 & 0.52 \\
2010 & 3.50 & 1.03 & 2.32 & 0.79 \\
2018 & 4.50 & 1.13 & 3.52 & 0.98 \\
\hline
\end{tabular}

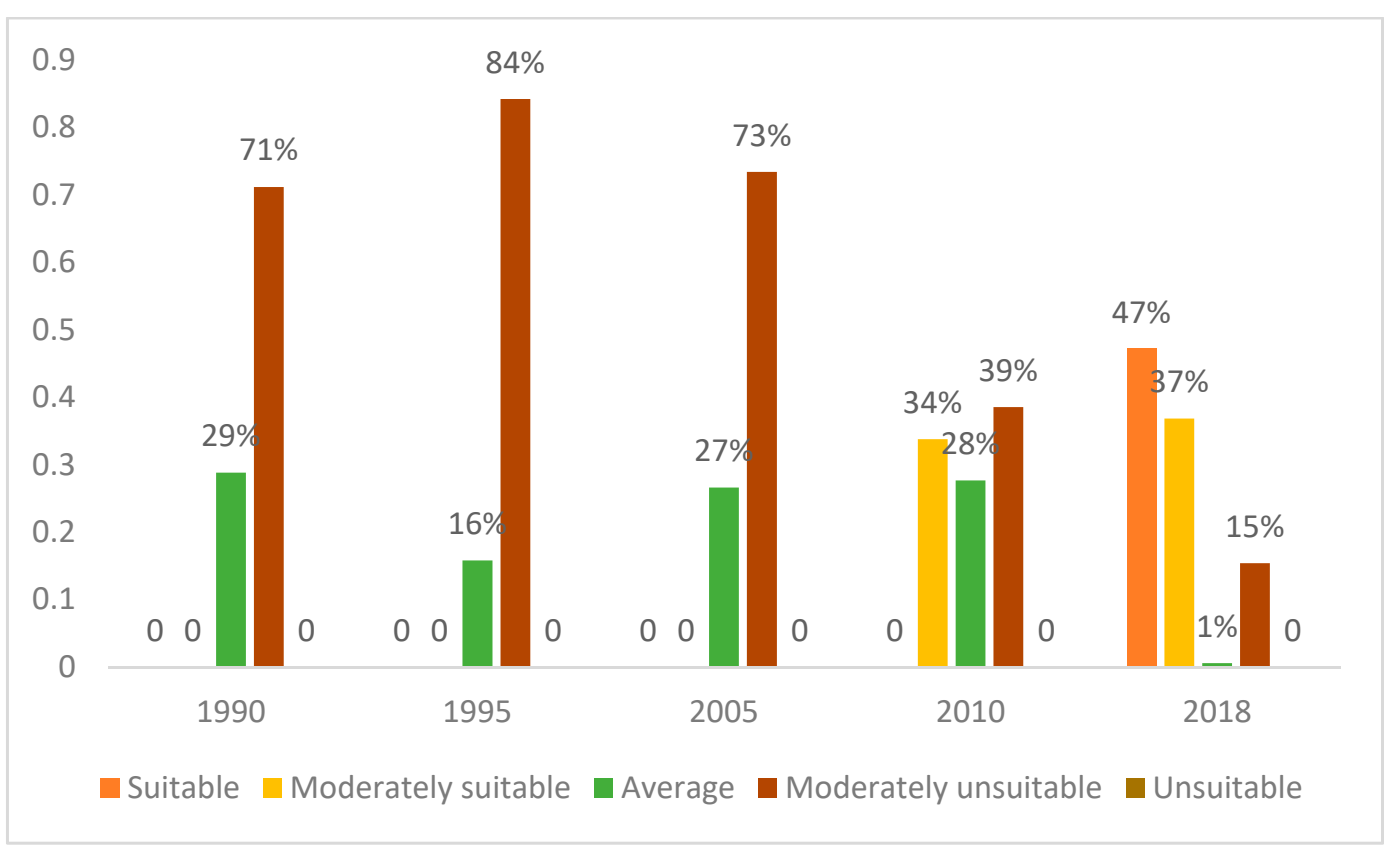

Figure 6. Proportional structure of number of grid cells for evaluation of functional suitability of ecological space.

\subsubsection{Changes in Functional Suitability of Agricultural-Production Space}

The lowest variability was found in the functional suitability of the agriculturalproduction space. In general, the suitability index of Zhulin's agricultural-production has not changed much, showing a gradual increase from an initial 3.29 in 1990 to 3.90 in 2018, and its overall suitability has remained in the moderately suitable interval. Based on the intragroup variation, the maximum value of the suitability index of Zhulin's agriculturalproduction space continued to increase, while the minimum value fluctuated only slightly. The standard deviations of the indicators ranged from 0.21 to 0.26 , and the overall variation was small, indicating no significant difference (Table 9). The main reason for this small variation is that the proportion of areas evaluated as moderately suitable for agriculturalproduction space in Zhulin remained high, and the gradual increase in the level of func- 
tional suitability was due to the upgrading of some moderately suitable areas to suitable areas (Figure 7).

Table 9. Overall evaluation of functional suitability of agricultural-production space.

\begin{tabular}{ccccc}
\hline Year & Max. & Min. & Mean & Standard Deviation \\
\hline 1990 & 3.77 & 2.73 & 3.29 & 0.21 \\
1995 & 3.77 & 2.63 & 3.32 & 0.21 \\
2005 & 4.08 & 3.07 & 3.63 & 0.21 \\
2010 & 4.38 & 3.28 & 3.93 & 0.23 \\
2018 & 4.38 & 2.78 & 3.90 & 0.26 \\
\hline
\end{tabular}

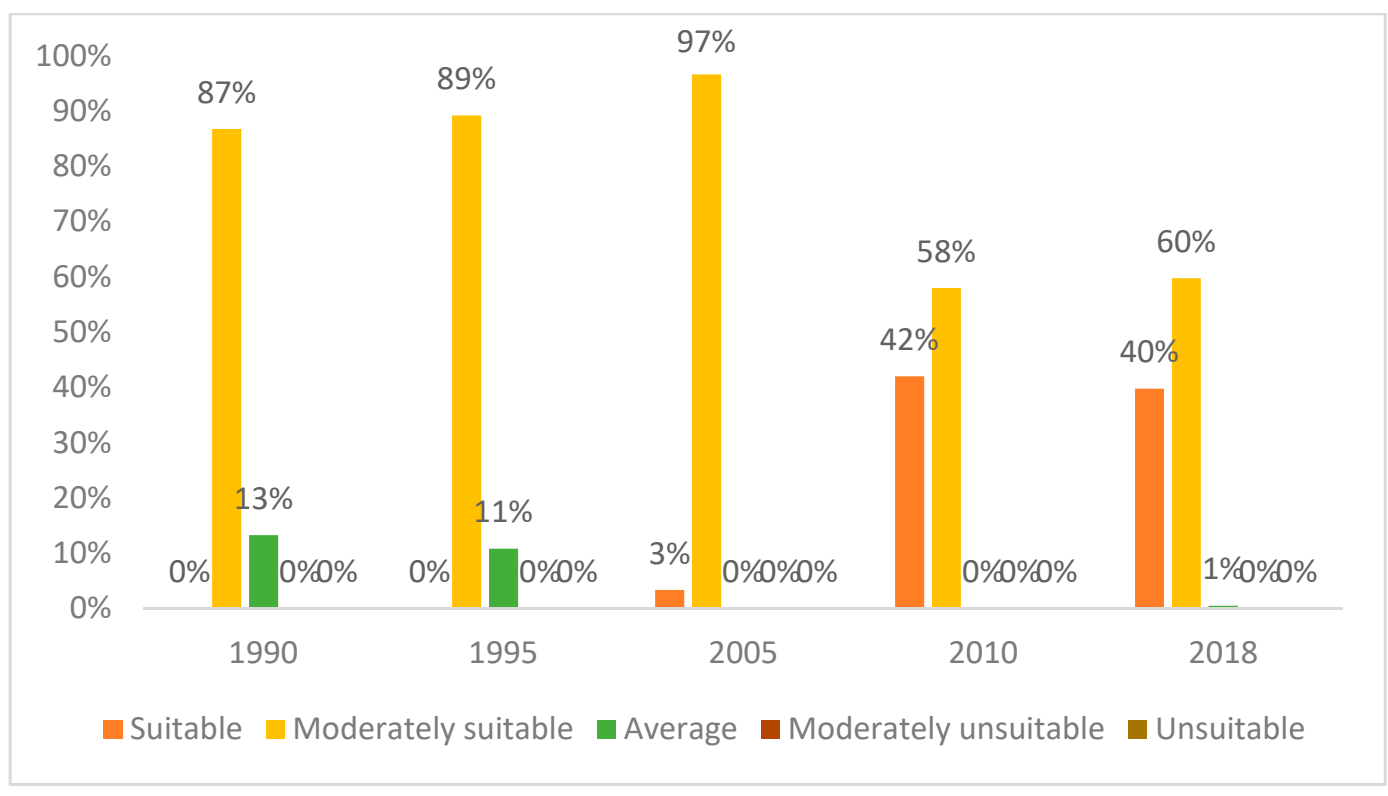

Figure 7. Proportional structure of number of grid cells for evaluation of functional suitability of agriculturalproduction space.

\subsubsection{Changes in Functional Suitability of Nonagricultural-production Space}

The mean value of the functional suitability for the nonagricultural-production space was the highest and most stable. In general, the average suitability index of Zhulin's nonagricultural-production space had a smaller variation, showing a small fluctuation and increasing trend, and the evaluation of its overall suitability remained in the interval of moderately suitable. Based on the intragroup variation, the maximum value of the suitability index for the nonagricultural-production space remained almost unchanged, while the minimum value showed a fluctuating decreasing trend. The standard deviations of the indicators ranged from 0.40 to 0.60 , and the overall sample dispersion was not high and showed a small fluctuating increase, indicating that the difference between the samples showed a small fluctuation (Table 10). The reason for this phenomenon is that the suitability evaluation of nonagricultural-production space was mainly moderately suitable and suitable in general, with no grid cells of moderately unsuitable and unsuitable. The proportion of grid cells evaluated as suitable declined between 2005 and 2010, but then improved and exceeded the proportion of moderately suitable grid cells, becoming dominant (Figure 8). 
Table 10. Overall evaluation of functional suitability of nonagricultural-production space.

\begin{tabular}{ccccc}
\hline Year & Max. & Min. & Mean & Standard Deviation \\
\hline 1990 & 4.73 & 2.97 & 3.88 & 0.47 \\
1995 & 4.78 & 2.14 & 3.80 & 0.60 \\
2005 & 4.73 & 2.09 & 3.82 & 0.46 \\
2010 & 4.73 & 2.85 & 3.86 & 0.40 \\
2018 & 4.78 & 2.31 & 4.00 & 0.51 \\
\hline
\end{tabular}

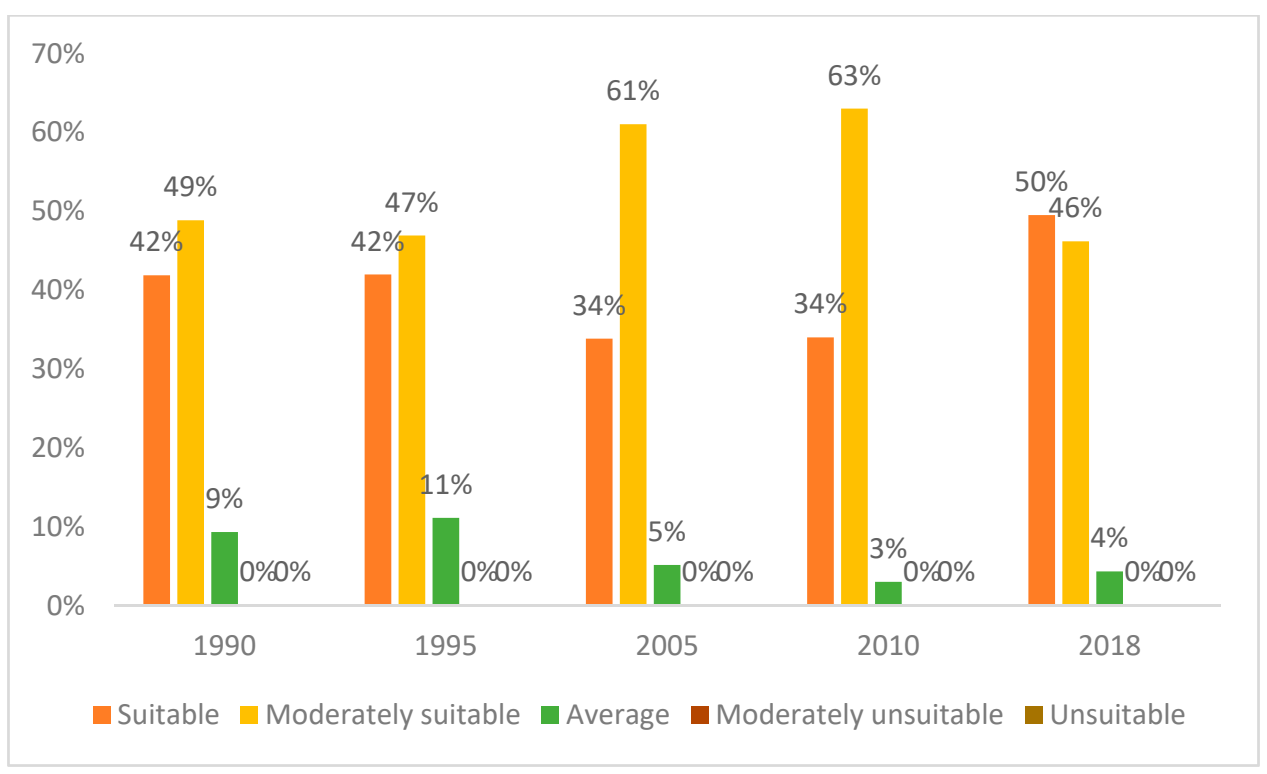

Figure 8. Proportional structure of number of grid cells for evaluation of functional suitability of nonagriculturalproduction space.

\subsubsection{Changes in Functional Suitability of Living Space}

The greatest difference was found in the functional suitability of the living space. In general, the average suitability indexes of Zhulin's living space first increased, then decreased, and finally increased gradually. Overall, the changes were minor, showing a slight increase with fluctuation. The evaluation of the overall suitability was always in the interval of moderately suitable (Table 11). Based on the intragroup variation, the maximum value of the living space suitability index continued to increase slightly, while the minimum value showed a small decrease. The standard deviations of the indicators ranged from 0.94 to 1.13 , the highest dispersion in the EPL spaces, and showed a small fluctuating increase, indicating that the difference between samples was relatively large in the EPL spaces. According to the structure of the grid distribution, although moderately suitable and suitable were also dominant in general, the average and moderately unsuitable grid cells in different years accounted for a notable proportion. Despite the overall suitability remaining at a relatively high level and the proportion of grid cells evaluated as suitable and moderately suitable increasing, internal differentiation has not improved much (Figure 9).

Table 11. Overall evaluation of functional suitability of living space.

\begin{tabular}{ccccc}
\hline Year. & Max. & Min. & Mean & Standard Deviation \\
\hline 1990 & 4.31 & 0.90 & 3.18 & 1.02 \\
1995 & 4.73 & 0.90 & 3.29 & 1.04 \\
2005 & 4.73 & 0.90 & 3.83 & 0.94 \\
2010 & 4.79 & 0.60 & 3.46 & 1.13 \\
2018 & 4.79 & 0.60 & 3.58 & 1.04 \\
\hline
\end{tabular}




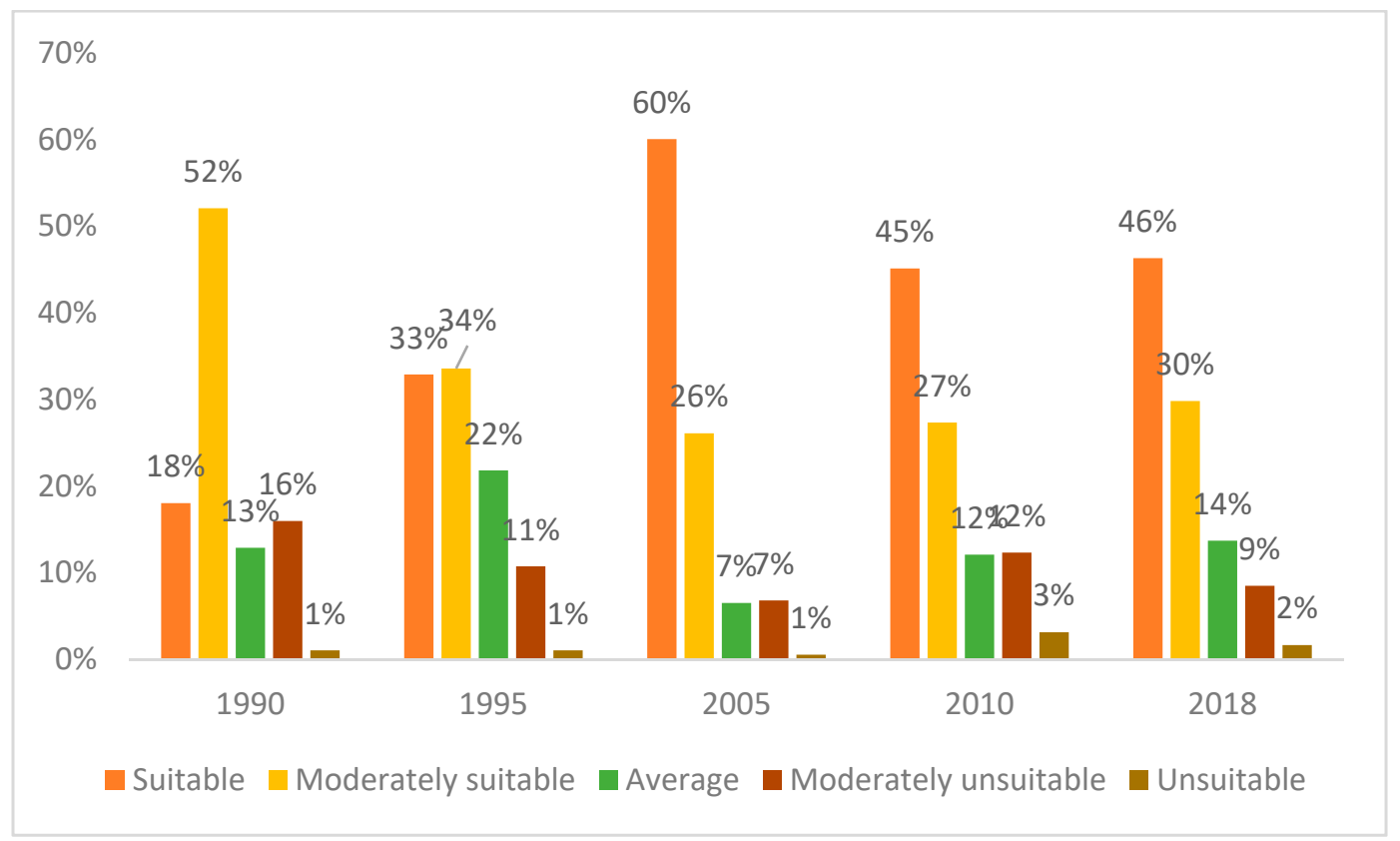

Figure 9. Proportional structure of number of grid cells for evaluation of functional suitability of living space.

\subsection{EPL Analysis of Matching between Distribution of EPL Spaces and Their Functional Suitability}

Since the administrative area of Zhulin changed several times during the study period, we analyzed the match between the distribution of the EPL spaces and their functional suitability in different time periods, in a comprehensive manner, by using the overall estimated administrative area of each period (Figure 10) and considering only the match between the distribution of the internal EPL spaces and their functional suitability, excluding external new areas (Figure 11).

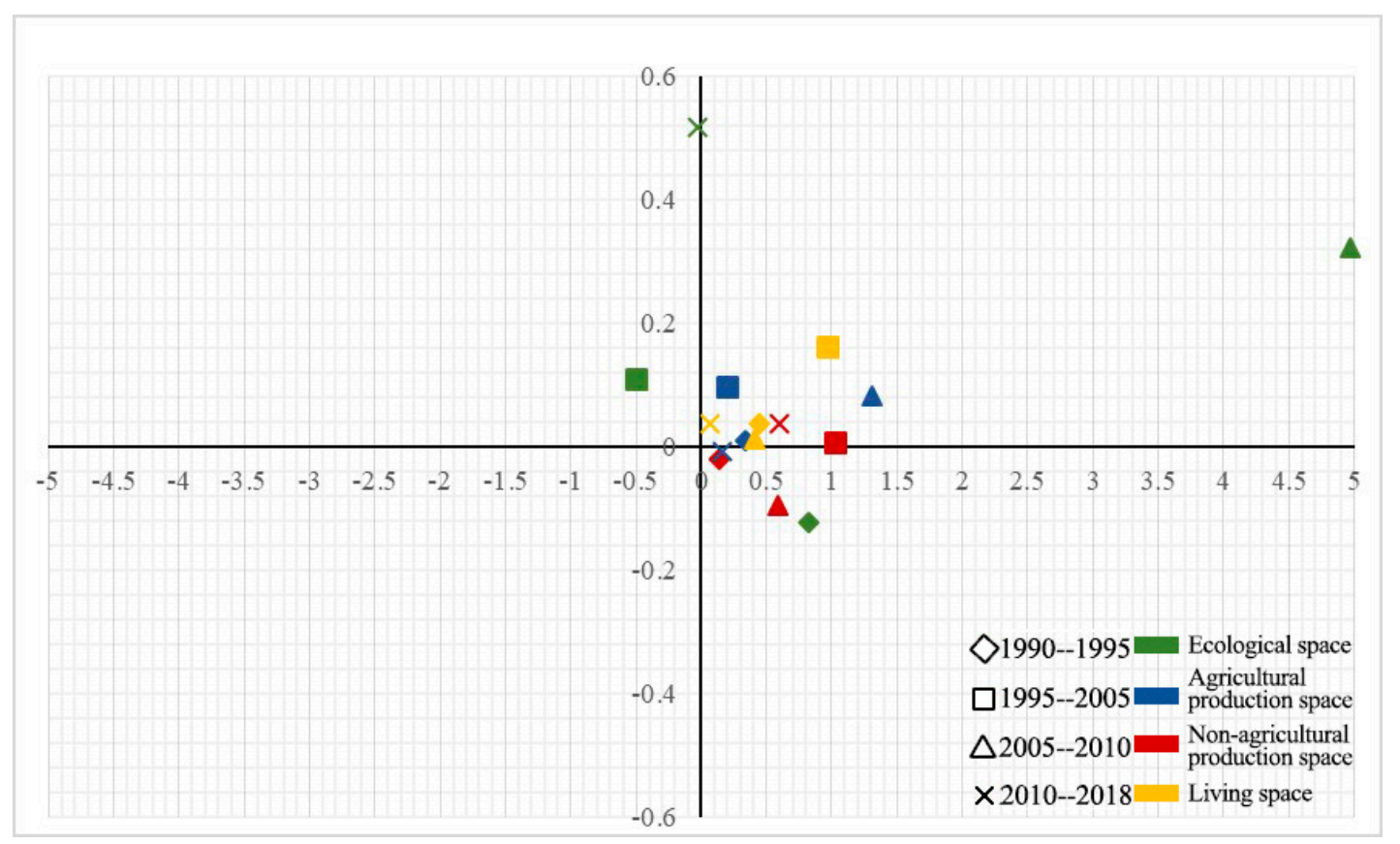

Figure 10. Match between overall distribution and functional suitability of Zhulin's EPL spaces. 


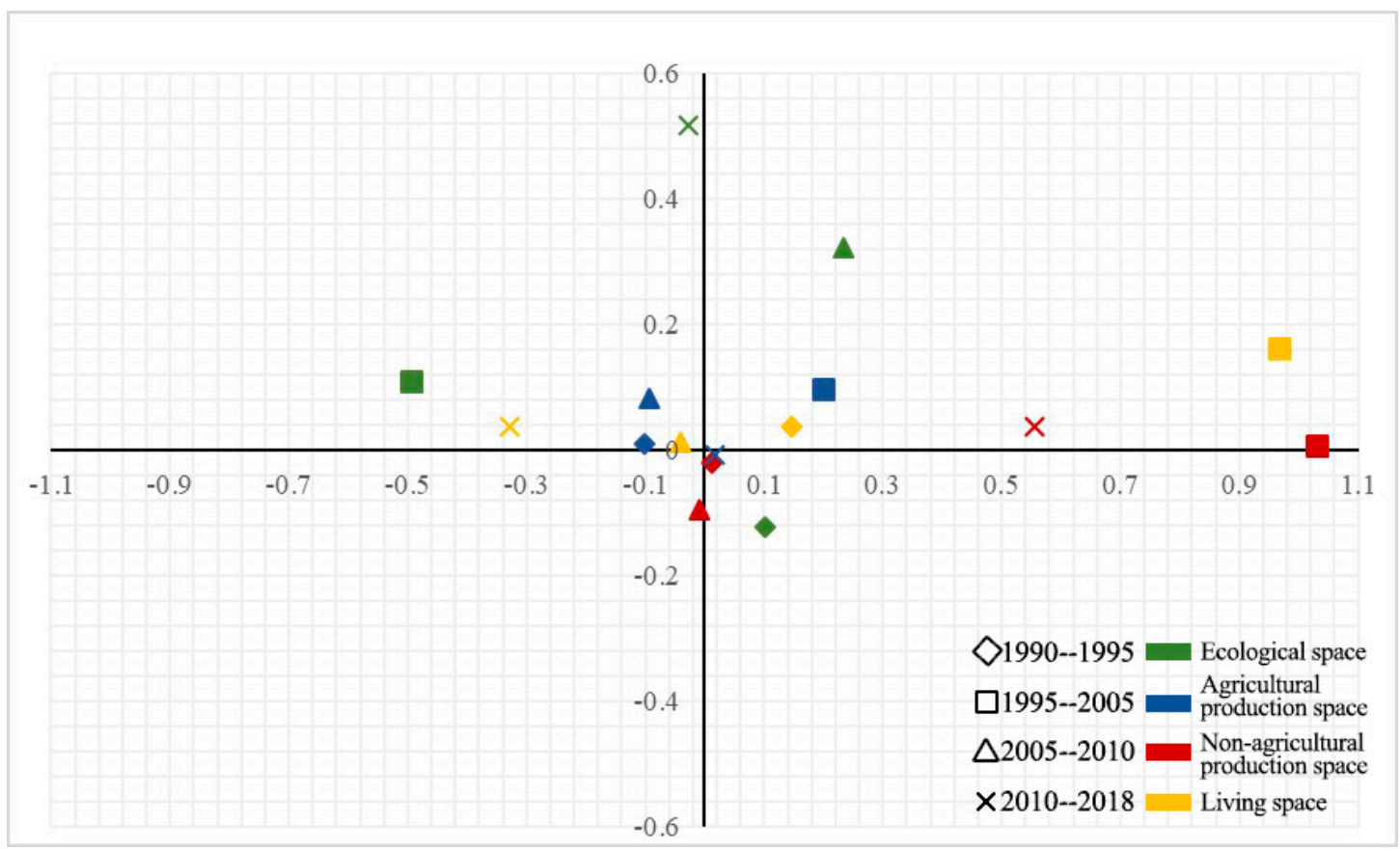

Figure 11. Match between internal distribution and functional suitability of Zhulin's EPL spaces.

In general, due to changes in administrative divisions, economic development and infrastructure construction, the following features emerged in the matching patterns between the distribution and functional suitability of Zhulin's EPL spaces from 1990 to 2018:

1. The restructuring of Zhulin's EPL spaces has generally achieved a positive effect. Owing to the continuous growth of the administrative area of Zhulin, the overall expansion trend for various types of spaces is significant, except for ecological space in some individual periods, and $62.5 \%$ of the matching cases fall into the first quadrant, a high-quality growth type. The restructuring of Zhulin's EPL spaces has achieved a positive effect. However, the quality of expansion differs in different periods.

2. Most of the spatial high-quality growth occurred in the period 1995-2005. The administrative area of Zhulin did not change during this period. The distribution and functional suitability of the agricultural-production space, nonagricultural-production space and living space in this period all fell into the first quadrant, which is in the highquality growth area. The ecological space, however, fell into the second quadrant, in the area of functional optimization and intensification.

3. Spatial low-quality expansion occurred mainly in the 1990-1995 period. In this period, along with the expansion of Zhulin's administrative area, both ecological space and nonagricultural-production space grew, but their functional suitability declined both in general and in terms of internal changes. Furthermore, the match between the distribution and functional suitability of its ecological space and nonagriculturalproduction space fell in the fourth quadrant, in the low-quality expansion area.

4. The overall match for the agricultural-production space and living space was good in different years. In terms of both overall changes and internal changes, the living space was in the first and second quadrants of continuous functional optimization, and entirely in the high-quality growth area. The agricultural-production space was also in the first and second quadrants of continuous functional optimization. Except for 2018, when there was low-quality expansion, the changes in all the other periods were in the high-quality growth area. This is mainly due to the fact that economic development has made it possible for Zhulin to vigorously improve water supply conditions, road facilities and other basic infrastructure conditions, thus increasing the suitability for living and agricultural production. 
5. Low-quality expansion of the nonagricultural-production space occurred most frequently. Low-quality expansion of nonagricultural industrial space appeared in the periods 1990-1995 and 2005-2010, corresponding to the period of early development and the period of administrative area expansion, respectively. Led by economic interests, governments' management of land policy began to loosen, and enterprises developed in a disorderly manner in the pursuit of profits, resulting in the low-quality expansion of nonagricultural industrial space. However, in the 2010-2018 period, the nonagricultural industrial space (after the administrative area expansion) witnessed high-quality growth, mainly because Zhulin began to orient its development toward tourism so that the location decisions of enterprises no longer pursued size alone, leading to relatively higher-quality development.

\section{Discussion}

The main purpose of analyzing the history of rural-spatial restructuring is to grasp the patterns of its changes, which can ultimately be applied to the improvement of rural land space, with the goal of optimizing the spatial pattern of rural land, improving the efficiency of land resource utilization and enhancing its spatial quality. However, most of the literature takes the perspective of EPL's spatially explicit attributes, i.e., changes in area, structure or spatial distribution, while few studies address whether structural changes match functional suitability. This makes it impossible to grasp the overall picture of the functional evolution of spatial structure, which affects our scientific judgment and the implementation and formulation of policies. For example, in the process of the spatial restructuring of Zhulin, from 1995 to 2005, ecological spaces suffered a large reduction simply in terms of quantitative and structural changes. According to the traditional analysis paradigm [25-27], this point, a turning point in ecological spatial area change, often heralds a sudden change in ecological space, which may lead to its dysfunction. However, the results of the functional suitability evaluation show that the functional suitability of Zhulin's ecological, living, agricultural-production and nonagricultural-production spaces continued to increase during this period. This indicates that the path of development in this period was substantially in line with the actual local situation. The integration of land-use distribution has led to the continuous optimization of local land-use functions, resulting in an overall increase in the efficiency of land and space use. This is why Zhulin was awarded the title of China's Sustainable Small Town Pilot by UNDP during this period, and why it was also awarded the Dubai International Award for Best Practice in Improving the Living Environment by UN-Habitat in 2002.

Clearly, the process of land-use transformation influenced by land-resource allocation and management is complex, because the value of a land-use type relative to its competing uses changes over time [42]. Therefore, analysis of EPL spatial restructuring with a onesided emphasis on area change may not fully capture the functional suitability of rural spaces, which may lead to difficulty in adequately matching the restructuring of EPL spaces to the territorial spaces in which they are located. If so, the actual value of allocated land may be far from optimal, distorting economic and political incentives and undermining the sustainability of the countryside [56]. This will result in the previous practice of simply pursuing increases in the area of certain types of land use while ignoring whether functional suitability is satisfied, risking the repetition of tragedies in human-land relations such as the enclosure of lakes to create fields, the reclamation of land, steep slope clearing and deforestation (grass clearing). Therefore, in analyzing rural-spatial restructuring, it is necessary to consider not only changes in explicit morphological characteristics but also changes in implicit characteristics, represented by quality and function [23].

Taking Zhulin Town as a case study, this paper sets forth a spatial-restructuring analysis method based on the evaluation of the land distribution and functional suitability of EPL spaces and analyzed the spatial-restructuring process over the past 30 years of reform and opening up. 
We propose a method for studying rural-spatial restructuring based on changes in the dominant and recessive morphologies of land use. That will enable us to understand the process of rural-spatial restructuring more comprehensively from the changes in both the dominant and recessive morphologies of land use. The development of Zhulin from a remote mountain village to a modern town is essentially a condensed version of the development of China's rural urbanization, and its rural-spatial restructuring process essentially reflects the impact of the shift in national macro development policies on rural development. Before 2000, China was still in a period of economic construction, and the goal of economic development overruled all other considerations. At that time, no clearly delineated land-use guidelines were issued at the national level, and land-use and development guidelines were set by local governments [57]. Under the policy orientation of overriding economic development, local governments tended to blindly expand production space to bring about more economic benefits without considering other factors. This is why Zhulin's low-quality expansion occurred mainly between 1990 and 1995 and the functional suitability of EPL spaces declined in this period. The early 21st century witnessed the conversion of a lot of arable land by urbanization and industrialization, resulting in a significant decrease in the rural labor force engaged in agricultural production; the output efficiency of arable land decreased, affecting national food security. Therefore, the Ministry of Land and Resources of China launched the first ten-year (2001-2010) national plan focusing on maintaining a dynamic balance of arable land to rearrange and reclaim, and to develop idle, abandoned and damaged land to increase the quantity and improve the quality of arable land [58]. Top-down policy constraints enabled the recovery of arable land area in various places during this period. It was also during this period that Zhulin's proportion of agricultural-production space peaked. At the same time, the ecological and environmental problems associated with China's rapid urbanization became increasingly apparent. The expansion of land for construction led to landscape fragmentation, environmental degradation and the destruction of ecosystem services [59]. Faced with these problems and challenges, since 2012, China has proposed a shift in the spatial development model for its land from a production-space orientation to ecologicalproduction-living coordination to optimize the spatial layout of land and alleviate the contradiction between urban and rural development [22]. This is why Zhulin's ecological spatial area decreased from 2010 to 2018, while its functional suitability was significantly enhanced in this period. The same is true for the functional suitability of other space types.

Macro development policy is a powerful mechanism by which to influence regional and rural development [60]. The spatial restructuring of Zhulin over the past 30 years reflects a good fit with the national policy shift. This is not easy for local governments to achieve and is the most important reason why Zhulin's economic and social development is sustainable. The timely adjustment of Zhulin's development pattern within its administrative division in response to the national policy shift is due to its good rural-governance model. Within the framework of China's grassroots self-governance system, Zhulin has developed a governance model system that includes two aspects, which are named "San Ping" and "Shi Ping" in Chinese. The "San Ping" refers to a process of evaluating the governance of village leaders and cadres through a mechanism of public supervision. The "Shi Ping" refers to a practice of evaluating top performers among the masses to motivate them to make contributions in the process of Zhulin's development. This mode of governance can actively mobilize the grassroots to participate in politics, and help to unify the ideologies of all the villagers, so that local actors can grasp development opportunities in a timely manner and correct problems that arise in the development process, thus promoting Zhulin's high-quality development.

With the transformation of the rural economy, the economic importance of agricultural land will continue to decline, while the function of land as a space carrier, an asset and capital will increase. This trend will eventually lead to a return to the stable state of the agricultural-production function and ecological landscape function. This trend will be mapped to land-use pattern changes. During periods when land-use patterns cannot adapt 
to rural development needs, there will be various land-use problems, which will require the reasonable intervention of local actors to adjust the land-use patterns to, again, adapt them to development needs. The most important reason for this is that, under the influence of the current stage of rural grassroots autonomy policy, the impact of external national or regional macro policies and changes in the market environment on the development of villages needs to be determined more through the awareness of elected leaders and competent people in the village concerning the relevant policies and changes in the market environment [61,62]. Local actors are often the centerpiece of the rural development process [63]. It is therefore crucial for local actors to intervene reasonably and to respond proactively in the interactive process of land-use and village development $[64,65]$.

It should be pointed out that there are still some problems worthy of further discussion, such as the in-depth analysis of the evolution mechanism of spatial restructuring promoted by land-use transitions. We need to consider more complex and diverse issues when we take a relatively micro area, such as Zhulin Town, as a study area to perform a long-term study. We not only need to consider the influence of its own development conditions and external development conditions, but also need to consider the influence of some accidental factors. Therefore, it is difficult to study its evolution mechanism. Research on its mechanism is of great significance for promoting the coordinated development of urban and rural areas. It needs to be further strengthened. In addition, the suitability of function is only one of the characteristics of the recessive morphology of land-use morphologies. The recessive morphologies also include land-use management systems, property rights and so on. As the impact of recessive morphologies on land-use transformation will gradually increase $[17,23]$, more in-depth research should be carried out in the future.

\section{Conclusions}

Based on land-use type, this paper has established a framework for the identification of EPL spaces and constructed an evaluation system for the functional suitability of EPL spaces. Based on this framework, we propose criteria for judging the match between the distribution of EPL spaces and their functional suitability in terms of changes in their quantitative distribution and functional suitability characteristics. We used Zhulin Town in Central China as a case study area to analyze its rural-spatial restructuring process since 1990. The regional characteristics of the spatial distribution of the ecological and agricultural-production space were made clear. The clustering trend of the living space and nonagricultural-production space has strengthened, especially for the living space. Many scattered living spaces have begun to die out, while living and nonagriculturalproduction spaces along main transportation routes have continued to expand. Overall, Zhulin is dominated by agricultural-production and ecological space. The structure of its EPL spaces has fluctuated over the past 30 years, with the proportion of production space (including agricultural-production and nonagricultural-production space) and living space first decreasing and then increasing, and then decreasing again, yielding a $\mathrm{W}$-shaped fluctuation curve. The change in the proportion of Zhulin's ecological space is opposite to that in its production and living spaces, showing an M-shaped fluctuation curve. The fluctuation in EPL spaces is due to the expansion of Zhulin's administrative space as well as its own internal transformation. Although the distribution and structure of EPL spaces have been changing over the past 30 years, their overall functional suitability has steadily increased. Analysis of the distribution and functional suitability of Zhulin's EPL spaces revealed a significant trend of expansion for various types of spaces in general, and $62.5 \%$ of the matching types were of high-quality growth, which shows that the restructuring of Zhulin's EPL spaces has achieved a more positive effect. High-quality spatial growth occurred mainly in the 1995-2005 period, and low-quality spatial expansion occurred mainly in the 1990-1995 period. The overall match for Zhulin's agricultural-production space and living space was good in some years, and nonagricultural-production space showed the most low-quality expansion. 
This case study of Zhulin shows that a spatial restructuring study combining changes in spatial area, the quantity of EPL spaces, and changes in functional suitability generates a more comprehensive understanding of the process of restructuring. It also helps to improve understanding of the impact of the shift in national macro development policies on rural development. Thus, future studies on rural-spatial restructuring should consider changes in the explicit morphological characteristics of the land as well as changes in the implicit characteristics represented by quality and function. Rural-spatial restructuring requires local actors to make timely adjustments to meet the needs of macroeconomic and social development, while a good rural-governance model serves as an important guarantee to ensure that rural-spatial functions can be optimized. In the future, we should strengthen the research on the mechanism of land-use transitions promoting rural restructuring and the influence of recessive morphologies on land-use transformation.

Author Contributions: Conceptualization, D.H. and J.Q.; methodology, D.H. and J.Q.; formal analysis, D.H.; data curation, D.H. and Q.Z.; writing-original draft preparation, D.H.; writing-review and editing, J.Q. and Q.Z.; visualization, Q.Z.; supervision, J.Q.; funding acquisition, J.Q. All authors have read and agreed to the published version of the manuscript.

Funding: This research was funded by National Natural Science Foundation of China (42071220 and 41671172) and Philosophy and Social Science Innovative Talent Project of Higher Education in Henan Province (2021-CX-016).

Acknowledgments: We wish to thank the kind local villagers who were willing to be interviewed and the local government departments of Zhulin town and Gongyi City for providing relevant information.

Conflicts of Interest: The authors declare no conflict of interest.

\section{References}

1. Elshof, H.; Haartsen, T.; Van Wissen, L.J.G.; Mulder, C.H. The influence of village attractiveness on flows of movers in a declining rural region. J. Rural Stud. 2017, 56, 39-52. [CrossRef]

2. Woods, M. Rural Geography: Processes, Responses and Experiences in Rural Restructuring; Sage: London, UK, $2005 ;$ pp. $29-41$. [CrossRef]

3. Long, H. Land consolidation: An indispensable way of spatial restructuring in rural China. J. Geogr. Sci. 2014, 24, 211-225. [CrossRef]

4. Woods, M. Engaging the global countryside: Globalization, hybridity and the reconstitution of rural place. Prog. Hum. Geogr. 2007, 31, 485-507. [CrossRef]

5. Galani-Moutafi, V. Rural space (re)produced-practices, performances and visions: A case study from an Aegean island. J. Rural Stud. 2013, 32, 103-113. [CrossRef]

6. Hedlund, M.; Lundholm, E. Restructuring of rural Sweden: Employment transition and out-migration of three cohorts born 1945-1980. J. Rural Stud. 2015, 42, 123-132. [CrossRef]

7. Ellis, F.; Biggs, S. Evolving themes in rural development 1950s-2000s. Dev. Policy Rev. 2001, 19, 437-448. [CrossRef]

8. Lobley, M.; Potter, C. Agricultural change and restructuring: Recent evidence from a survey of agricultural households in England. J. Rural Stud. 2004, 20, 499-510. [CrossRef]

9. Nelson, P.B. Rural restructuring in the American West: Land use, family and class discourses. J. Rural Stud. 2001, 17, 395-407. [CrossRef]

10. Wilson, O.J. Rural restructuring and agriculture-rural economy linkages: A New Zealand study. J. Rural Stud. 1995, 11, 417-431. [CrossRef]

11. Li, Y.; Westlund, H.; Liu, Y. Why some rural areas decline while some others not- An overview of rural evolution in the world. J. Rural Stud. 2019, 68, 135-143. [CrossRef]

12. Echánove, F. Globalization and restructuring in rural Mexico: The case of fruit growers. Tijdschr. Econ. Soc. Geogr. 2005, 96, 15-30. [CrossRef]

13. Tu, S.; Long, H.; Zhang, Y.; Ge, D.; Qu, Y. Rural restructuring at village level under rapid urbanization in metropolitan suburbs of China and its implications for innovations in land use policy. Habitat Int. 2018, 77, 143-152. [CrossRef]

14. Liu, Y.; Long, H.; Chen, Y.; Wang, J.; Li, Y.; Li, Y.; Yang, Y.; Zhou, Y. Progress of research on urban-rural transformation and rural development in China in the past decade and future prospects. J. Geogr. Sci. 2016, 26, 1117-1132. [CrossRef]

15. Liu, Y.; Yan, B.; Wang, Y. Urban-rural development problems and transformation countermeasures in the new period in China. Econ. Geogr. 2016, 36, 1-8. (in Chinese). [CrossRef]

16. Tu, S.; Long, H. Rural restructuring in China: Theory, approaches and research prospect. J. Geogr. Sci. 2017, 27, 1169-1184. [CrossRef] 
17. Long, H. Land Use Transitions and Rural Restructuring in China; Springer Nature: Singapore, 2020; pp. 31-160. [CrossRef]

18. Long, H.; Li, Y.; Liu, Y.; Woods, M.; Zou, J. Accelerated restructuring in rural China fueled by 'increasing vs. decreasing balance' land-use policy for dealing with hollowed villages. Land Use Policy 2012, 29, 11-22. [CrossRef]

19. Long, H.; Woods, M. Rural Restructuring under Globalization in Eastern Coastal China— What can we learn from Wales? J. Rural Community Dev. 2011, 6, 70-94.

20. Huang, A.; Xu, Y.; Lu, L.; Liu, C.; Zhang, Y.; Hao, J.; Wang, H. Research progress of the identification and optimization of production-living-ecological spaces. Prog. Geogr. 2020, 39, 503-518. (in Chinese). [CrossRef]

21. Long, H. Land consolidation and rural spatial restructuring. Acta Geogr. Sin. 2013, 68, 1019-1028. (In Chinese)

22. Yang, Y.; Bao, W.; Li, Y.; Wang, Y.; Chen, Z. Land use transition and its eco-environmental effects in the Beijing-Tianjin-Hebei urban agglomeration-A production-living-ecological perspective. Land 2020, 9, 285. [CrossRef]

23. Long, H.; Qu, Y.; Tu, S.; Zhang, Y.; Jiang, Y. Development of land use transitions research in China. J. Geogr. Sci. 2020, 30, 1195-1214. [CrossRef]

24. Zhou, X.; Li, X.; Song, W.; Kong, X.; Lu, X. Farmland transitions in China: An advocacy coalition approach. Land 2021, 10, 122. [CrossRef]

25. Bertoni, D.; Aletti, G.; Ferrandi, G.; Micheletti, A.; Cavicchioli, D.; Pretolani, R. Farmland use transitions after the CAP greeningA preliminary analysis using Markova chains Approach. Land Use Policy 2018, 79, 789-800. [CrossRef]

26. Ge, D.; Long, H.; Zhang, Y.; Ma, L.; Li, T. Farmland transition and its influences on grain production in China. Land Use Policy 2018, 70, 94-105. [CrossRef]

27. You, $\mathrm{H}$.; Hu, X.; Wu, Y. Farmland use intensity changes in response to rural transition in Zhejiang province, China. Land Use Policy 2018, 79, 350-361. [CrossRef]

28. Long, H.; Heilig, G.K.; Li, X.; Zhang, M. Socio-economic development and land-use change-Analysis of rural housing land transition in the Transect of the Yangtse River, China. Land Use Policy 2007, 24, 141-153. [CrossRef]

29. Qu, Y.; Jiang, G.; Li, Z.; Tian, Y.; Wei, S. Understanding rural land use transition and regional consolidation implications in China. Land Use Policy 2019, 82, 742-753. [CrossRef]

30. Ma, W.; Jiang, G.; Zhang, R.; Li, Y.; Jiang, X. Achieving rural spatial restructuring in China-A suitable framework to understand how structural transitions in rural residential land differ across peri-urban interface? Land Use Policy 2018, 75, 583-593. [CrossRef]

31. Yu, Z.; Xiao, L.; Chen, X.; He, Z.; Guo, Q.; Vejre, H. Spatial restructuring and land consolidation of urban-rural settlement in mountainous areas based on ecological niche perspective. J. Geogr. Sci. 2018, 28, 131-151. [CrossRef]

32. Sun, J.; Lu, B.; Chen, R.; He, C. The approach of village system spatial reconstruction on the background of urban-rural integration-A case study of Jiuduhe town in Huairou district of Beijing. Urban Stud. 2009, 16, 75-81, 107. (In Chinese) [CrossRef]

33. Li, T.; Long, H.; Liu, Y.; Tu, S. Multi-scale analysis of rural housing land transition under China's rapid urbanization: The case of Bohai Rim. Habitat Int. 2015, 48, 227-238. [CrossRef]

34. Xiao, J.; Ou, W. Study on the spatial restructure in the coordinated urban and rural development-A case study of Suqian city. China Land Sci. 2013, 27, 54-60, 97. (In Chinese) [CrossRef]

35. Du, X.; Wang, C.; Jiang, W.; Wan, Q.; Liu, Y. Rural settlements restructuring based on analysis of the gravity model at village level-The case of Dazhu village, Chongqing, China. Econ. Geogr. 2015, 35, 154-160. (In Chinese) [CrossRef]

36. Li, C.; Liang, S.; Che, Q. Spatial reconstruction of the rural settlements in Wuhu city based on the function oriented zoning. Resour. Environ. Yangtze Basin 2015, 24, 1736-1743. (In Chinese) [CrossRef]

37. Sun, H.; Liu, Y.; Xu, K. Hollow villages and rural restructuring in major rural regions of China-A case study of Yucheng City, Shandong Province. Chin. Geogr. Sci. 2011, 21, 354-363. [CrossRef]

38. Li, Y.; Liu, Y.; Long, H.; Cui, W. Community-based rural residential land consolidation and allocation can help to revitalize hollowed villages in traditional agricultural areas of China-Evidence from Dancheng County, Henan Province. Land Use Policy 2014, 39, 188-198. [CrossRef]

39. Gökyer, E. Understanding Landscape Structure Using Landscape Metrics; InTech: London, UK, 2013; pp. 663-676. [CrossRef]

40. Lambin, E.F.; Meyfroidt, P. Land use transitions: Socio-ecological feedback versus socio-economic change. Land Use Policy 2010, 27, 108-118. [CrossRef]

41. Long, H.; Li, T. The coupling characteristics and mechanism of farmland and rural housing land transition in China. J. Geogr. Sci. 2012, 22, 548-562. [CrossRef]

42. Long, H.; Qu, Y. Land use transitions and land management-A mutual feedback perspective. Land Use Policy 2018, 74, 111-120. [CrossRef]

43. Fang, C. Dissipative structure theory and geography system. Arid Land Geogr. 1989, 12, 53-58. (In Chinese)

44. De, Z.; Xu, J.; Lin, Z. Conflict or coordination?-Assessing land use multi-functionalization using production-living-ecology analysis. Sci. Total Environ. 2017, 577, 136-147. [CrossRef]

45. Yu, Z.; Xu, E.; Zhang, H.; Shang, E. Spatio-temporal coordination and conflict of production-living-ecology land functions in the Beijing-Tianjin-Hebei Region, China. Land 2020, 9, 170. [CrossRef]

46. Yang, Y.; Bao, W.; Liu, Y. Coupling coordination analysis of rural production-living-ecological space in the Beijing-Tianjin-Hebei region. Ecol. Indic. 2020, 117, 106512. [CrossRef]

47. Liu, J.; Liu, Y.; Li, Y. Classification evaluation and spatial-temporal analysis of "production-living-ecological" spaces in China. Acta Geogr. Sin. 2017, 72, 1290-1304. (In Chinese) [CrossRef] 
48. Steiner, F. Resource suitability: Methods for analyses. Environ. Manag. 1983, 7, 401-420. [CrossRef]

49. Fan, J.; Wang, Y.; Ouyang, Z.; Li, L.; Xu, Y.; Zhang, W.; Wang, C.; Xu, W.; Li, J.; Yu, J. Risk forewarning of regional development sustainability based on a natural resources and environmental carrying index in China. Earths Future 2017, 5, 196-213. [CrossRef]

50. Huang, J.; Lin, H.; Qi, X. A literature review on optimization of spatial development pattern based on ecological-production-living space. Prog. Geogr. 2017, 36, 378-391. (In Chinese) [CrossRef]

51. Yu, Z.; Zhang, W.; Liang, J.; Zhuang, L. Progress in evaluating suitability of spatial development and construction land. Prog. Geogr. 2015, 34, 1107-1122. (In Chinese) [CrossRef]

52. Mu, S.; Li, J.; Chen, Y.; Gang, C.; Zhou, W.; Ju, W. Spatial differences of variations of vegetation coverage in inner mongolia during 2001-2010. Acta Geogr. Sin. 2012, 67, 1255-1268. (In Chinese) [CrossRef]

53. He, B.; Ding, J.; Zhang, Z.; Abduwasit, G. Experimental analysis of spatial and temporal dynamics of fractional vegetation cover in Xinjiang. Acta Geogr. Sin. 2016, 71, 1948-1966. (In Chinese) [CrossRef]

54. Hansen, M.C.; DeFries, R.S.; Townshend, J.R.G.; Sohlberg, R.; Dimiceli, C.; Carroll, M. Towards an operational MODIS continuous field of percent tree cover algorithm-Examples using AVHRR and MODIS data. Remote Sens. Environ. 2002, 83, 303-319. [CrossRef]

55. Xu, Y.; Tang, Q.; Fan, J.; Bennett, S.J.; Li, Y. Assessing construction land potential and its spatial pattern in China. Landsc. Urban Plan. 2011, 103, 207-216. [CrossRef]

56. Barbier, E.B.; Burgess, J.C.; Grainger, A. The forest transition: Towards a more comprehensive theoretical framework. Land Use Policy 2010, 27, 98-107. [CrossRef]

57. Huang, Q.; Li, M.; Chen, Z.; Li, F. Land consolidation-An approach for sustainable development in rural China. AMBIO 2011, 40, 93-95. [CrossRef]

58. Tian, Y.; Liu, Y.; Liu, X.; Kong, X.; Liu, G. Restructuring rural settlements based on subjective well-being (SWB)—A case study in Hubei province, central China. Land Use Policy 2017, 63, 255-265. [CrossRef]

59. Qu, Y.; Long, H. The economic and environmental effects of land use transitions under rapid urbanization and the implications for land use management. Habitat Int. 2018, 82, 113-121. [CrossRef]

60. Brown, C.G.; Waldron, S.A.; Longworth, J.W. Rural development in China: Industry policy, regionalism, integration and scale. Int. J. Soc. Econ. 2005, 32, 17-33. [CrossRef]

61. Ren, G.; Zhu, X.; Heerink, N.; Feng, S.; van Ierland, E.C. Persistence of land reallocations in Chinese villages-The role of village democracy and households' knowledge of policy. J. Rural Stud. 2019. [CrossRef]

62. Li, Y.; Westlund, H.; Zheng, X.; Liu, Y. Bottom-up initiatives and revival in the face of rural decline: Case studies from China and Sweden. J. Rural Stud. 2016, 47, 506-513. [CrossRef]

63. Skinner, M.W.; Joseph, A.E.; Kuhn, R.G. Social and environmental regulation in rural China: Bringing the changing role of local government into focus. Geoforum 2003, 34, 267-281. [CrossRef]

64. Douglas, D.J.A. The restructuring of local government in rural regions: A rural development perspective. J. Rural Stud. 2005, 21, 231-246. [CrossRef]

65. Liu, Z.; Müller, M.; Rommel, J.; Feng, S. Community-based agricultural land consolidation and local elites: Survey evidence from China. J. Rural Stud. 2016, 47, 449-458. [CrossRef] 